KEY WORDS: Permeability

Waste Treatment

Super Cement

RETEntion: Permanent

\title{
STABILIZATION OF HIGH AND LOW SOLIDS CONSOLIDATED INCINERATOR FACILITY (CIF) WASTE WITH SUPER CEMENT
}

\author{
Author \\ B. W. WALKER, \\ Westinghouse Savannah River Company \\ Savannah River Technology Center, \\ Aiken, SC 29808
}

Date: September 30, 1999

Westinghouse Savannah River Company Savannah River Site Aiken, SC 29808

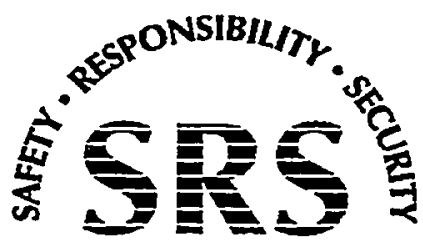




\section{Stabilization of High and Low Solids Consolidated Incinerator Facility (CIF) Waste with super Cement}

by

B. W. Walker

Westinghouse Savannah River Company

Savannah River Site

Aiken, South Carolina 29808

This paper was prepared in connection with work done under the above contract number with the U.S. Department of Energy. By acceptance of this paper, the publisher and/or recipient acknowledges the U.S. Government's right to retain a nonexclusive, royalty-free license in and to any copyright covering this paper, along with the right to reproduce and to authorize others to reproduce all or part of the copyrighted paper. 


\section{DISCLAIMER}

Portions of this document may be illegible in electronic image products. Images are produced from the best available original document. 


\section{DISCLAIMER}

This report was prepared as an account of work sponsored by an agency of the United States Government. Neither the United States Government nor any agency thereof, nor any of their employees, makes any warranty, express or implied, or -assumes any legal liability or responsibility for the accuracy, completeness, or usefulness of any information, apparatus, product, or process disclosed, or represents that its use would not infringe privately owned rights. Reference herein to any specific commercial product, process, or service by trade name, trademark, manufacturer, or otherwise does not necessarily constitute or imply its endorsement, recommendation, or favoring by the United States Government or any agency thereof. The views and opinions of authors expressed herein do not necessarily state or reflect those of the United States Government or any agency thereof.

This report has been reproduced directly from the best available copy.

Available to DOE and DOE contractors from the Office of Scientific and Technical Information, P.O. Box 62, Oak Ridge, TN 37831; prices available from (615) 576-8401.

Available to the public from the National Technical Information Service, U.S. Department of Commerce, 5285 Port Royal Road, Springfield, VA 22161. 
KEY WORDS: Permeability

Waste Treatment

Super Cement

RETENTION: Permanent

\title{
STABILIZATION OF HIGH AND LOW SOLIDS CONSOLIDATED INCINERATOR FACILITY (CIF) WASTE WITH SUPER CEMENT
}

\author{
Author \\ B. W. WALKER, \\ Westinghouse Savannah River Company \\ Savannah River Technology Center, \\ Aiken, SC 29808
}

Date: September 30, 1999

Westinghouse Savannah River Company Savannah River Site Aiken, SC 29808

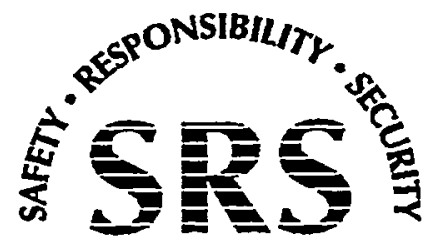


WSRC-TR-99-00359

Revision 0

September 30, 1999

REVIEWS AND APPROVALS

Author

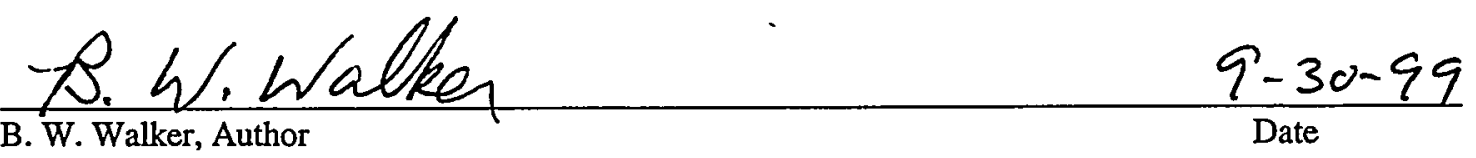

Waste Processing Technology

Approvals/Review

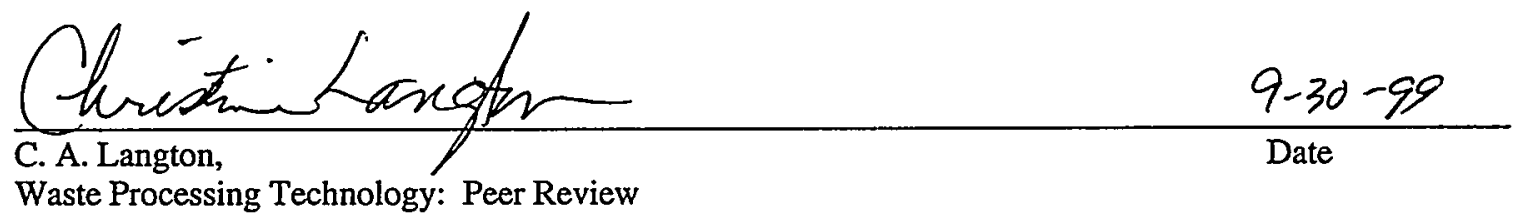

Waste Processing Technology: Peer Review

$\frac{\text { W.B. Van Pelt }}{\text { W. B. Van Pelt, Level } 4} \quad \frac{9-30-99}{\text { Date }}$

Waste Processing Technology

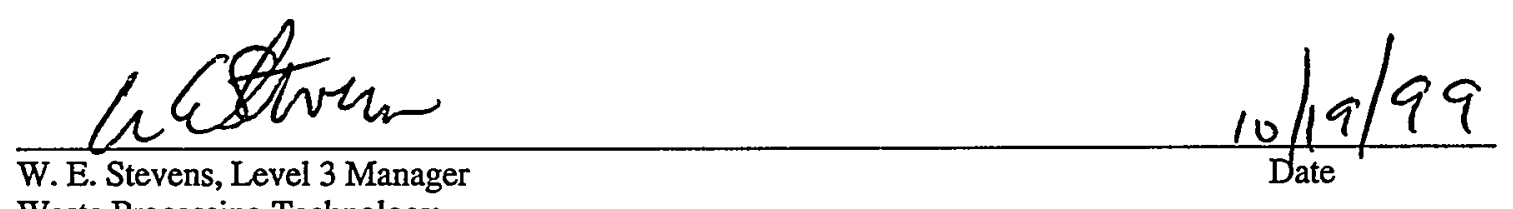

Waste Processing Technology 


\section{TABLE OF CONTENTS}

SUMMARY

EXPERIMENTAL

Waste Form Acceptance Criteria............................................ 4

Preparation of Super Cement ${ }^{\mathrm{TM}}$ Waste Forms...............................8

Preparation of Portland Cement Waste Forms...............................8

RESULTS

Processing Properties....................................................16

Cured Waste Form Properties............................................17

Permeability Results....................................................18

Compressive Strength..................................................21

Leaching Results.......................................................21

Waste Loading Results................................................24

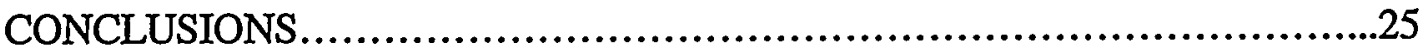

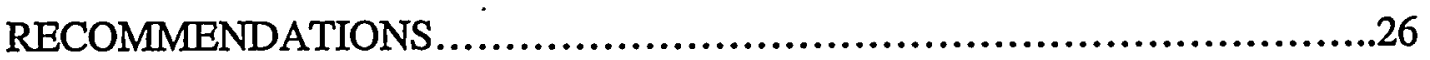

QUALITY ASSURANCE...................................................27

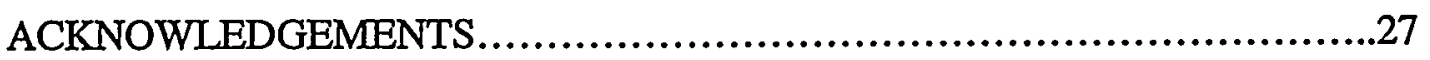

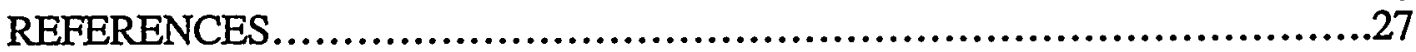

\section{TABLES}

Table I. Acceptance Criteria for Freshly Prepared Waste Forms..............4

Table II. Acceptance Criteria for Cured Waste Forms.........................4

Table III. High Solids Waste Form Compostion...............................10

Table IV. High Solids Waste Form Component Proportions...................11

Table V. Low Solids Waste Form Compostion................................13

Table VI. Low Solids Waste Form Component Proportions...................11

Table VII. High Solids Super Cement ${ }^{\mathrm{TM}}$ Processing Properties Eval........ 16

Table VIII.Low Solids Super Cement ${ }^{\mathrm{TM}}$ Processing Properties Eval........ 17

Table IX. High Solids Super Cement ${ }^{\mathrm{TM}}$ Cured Properties Evaluation........17

Table X. Low Solids Super Cement ${ }^{\mathrm{TM}}$ Cured Properties Evaluation.........18

Table XI. High Solids Portland Cement Waste Form Permeabilities..........19

Table XII. High Solids Super Cement ${ }^{\mathrm{TM}}$ Waste Form Permeabilities....... 19

Table XII. Low Solids Portland Cement Waste Form Permeabilities..... 20

Table XIV. Low Solids Super Cement ${ }^{\mathrm{TM}}$ Waste Form Permeabilities.......20

Table XV. TCLP Results for High Solids Portland Cement..................22

Table XVI. TCLP Results for Low Solids Waste Forms.....................23 
TABLES Continued

Table XVII. High Solids Waste Loadings.................................24

Table XVIII. Low Solids Waste Loadings................................24

FIGURES

Figure 1. ELE Permeameter............................................6

Figure 2. Permeameter Schematic.........................................

Figure 3. Centrifuge Internal Parts........................................9

Figure 4. Picture of UFA Centrifuge ....................................9

\section{APPENDICES}

Appendix 1. Characterization of Incinerator Waste..........................A1

Appendix 2. Permeabililty Calculations for Waste Forms....................A2

Appendix 3. ELE Permeability Procedure ................................A3 


\title{
STABILIZATION OF HIGH AND LOW SOLIDS CONSOLIDATED INCINERATOR FACILITY (CIF) WASTE WITH SUPER CEMENT (U)
}

\author{
B. W. Walker \\ Westinghouse Savannah River Company \\ Savannah River Technology Center \\ Aiken, SC 29808
}

\section{SUMMARY}

The Consolidated Incinerator Facility (CIF) at the Savannah River Site (SRS) burns low-level radioactive waste and mixed waste as a method of treatment and volume reduction. The CIF generates secondary waste, which consists of ash and off-gas scrubber solution. Currently the ash is stabilized/solidified in the Ashcrete process with Portland cement. The scrubber solution (blowdown) is sent to the SRS Effluent Treatment Facility (ETF) for treatment as waste water. In the past, the scrubber solution was also stabilized/solidified in the Ashcrete process as blowcrete and will continue to be treated this way for listed waste burns and scrubber solutions that do not meet the Effluent Treatment Facility (ETF) Waste Acceptance Criteria (WAC).

CIF has a need to upgrade/modify the secondary waste treatment stabilization process for ash and blowdown to give a waste form with better waste acceptance characteristics, increase production rate, and modify equipment so that there is less downtime/maintenance.

The Mixed Waste Focus Area (MWFA) had a list of stabilization technologies that were evaluated for possible deployment at CIF. Magnesium Phosphate Ceramic (Ceramicrete ${ }^{\mathrm{TM}}$ ) and Slag Cement (Super Cement ${ }^{\mathrm{TM}}$ ) technologies were chosen from the list as the best possible alternatives to Portland cement to stabilize ash and scrubber solution (blowdown) waste streams and were evaluated in this study.

One ash and blowdown waste stream solidified in this study was generated from incineration of radioactive diatomaceous earth filters (High Solids). A second ash and blowdown (Low Solids) waste stream solidified was generated from burning Purex waste and low level solid waste containing trace amounts of plutonium.

Waste Acceptance Criteria (WAC) used to evaluate solid waste forms generated are a minimum compressive strength of $500 \mathrm{psi}$, no leaching of hazardous metals above RCRA limits, no bleed water after 24 hours, a set time of less than 1 days, and a permeability of less than $1 \times 10^{-8} \mathrm{~cm} / \mathrm{sec}$. The SRS performance assessment model which qualified solid waste forms for trench land disposal required the $1 \times 10^{-8} \mathrm{~cm} / \mathrm{sec}$ permeability limits. Permeability was measured using a falling head method. Simulant permeabilities obtained with the falling head method were cross checked by centrifuge method analysis.

The Ceramicrete ${ }^{\mathrm{TM}}$ solidification of High Solids ash and blowdown part of this study is detailed in a previous report. ${ }^{1}$ Ceramicrete ${ }^{\mathrm{TM}}$ waste forms had unacceptable permeabilities and those containing blowdown exhibited crystallization cracking 
problems. For these reasons Ceramicrete ${ }^{\mathrm{TM}}$ solidification of Low Solids incinerator waste was not pursued.

High Solids Super Cement ${ }^{\mathrm{TM}}$ ash with setting agent solid waste forms pass acceptance criteria except for permeability. Initially High Solids Super Cement ${ }^{\mathrm{TM}}$ ash waste forms did not pass setting requirements. This problem was remedied by adding calcium hydroxide setting agent as a formulation modification. Super Cement is not acceptable for solidification of High Solids 30 wt \% blowdown solution waste forms because of permeability problems. The permeability of the waste form made with High Solids $10 \mathrm{wt} \%$ blowdown solution (unconcentrated) could not be determined because the sample was cracked.

Super Cement ${ }^{\mathrm{TM}}$ ash Low Solids waste forms pass SRS acceptance criteria but waste forms made with blowdown (at all concentrations) fail permeability requirements.

High Solids ash stabilized with Portland cement meet SRS acceptance criteria including permeability. The highest blowdown concentration for the High Solids waste that can be stabilized with Portland cement and meet all acceptance criteria is $10 \mathrm{wt} \%$ total solids (which is unconcentrated blowdown). Waste forms made with blowdown above this concentration do not meet permeability requirements.

Low Solids Portland Cement ash solid waste forms meet all acceptance requirements while Low Solids Portland Cement blowdown solid waste forms (at all concentrations) fail permeability requirements.

Super Cement ${ }^{\mathrm{TM}}$ is unsuitable for use to stabilize High Solids ash because it does not meet permeability requirements. Super Cement ${ }^{\mathrm{TM}}$ is not acceptable for $30 \mathrm{wt} \%$ blowdown solution waste forms because of permeability problems. It is acceptable to stabilize Low Solids ash but not blowdown (because blowdown waste forms do not meet permeability requirements). Other disadvantages to using Super Cement ${ }^{\mathrm{TM}}$ is that it is a more complicated process than Portland cement and it would require expensive plant modifications.

Portland cement is suitable to stabilize High Solids ash and blowdown up to $10 \mathrm{wt} \%$ total solids (unconcentrated blowdown). This technology also meets all acceptance requirements for Low Solids ash but fails permeability requirements for stabilizing Low Solids blowdown at any concentration.

Most of the waste forms for High and Low Solids are close to the $1 \times 10^{-8} \mathrm{~cm} / \mathrm{sec}$ permeability requirements for trench disposal of solidified waste forms. The performance assessment model used to generate these requirements will be evaluated again to see if samples that are more permeable might still result in waste forms that have acceptable leaching characteristics. If a more permeable sample is acceptable, Super Cement ${ }^{\mathrm{TM}}$ or Portland cement applications could be increased. 


\section{INTRODUCTION}

High Solids ash and scrubber solution waste streams were generated in the past at the incinerator facility at SRS by burning $\mathrm{M}$ area radioactive diatomaceous filter rolls which contained small amounts of uranium, and listed solvents (F and $U$ ). Low Solids ash and scrubber solution is currently being generated from incineration of a radioactive Purex waste containing small amounts of plutonium and other radionuclides.

Disposal plans for the CIF Ashcrete and Blowcrete depend on whether the waste burned in the incinerator is listed hazardous/mixed, characteristically hazardous/mixed, or radioactive. At the present time, SRS does not have an on-site disposal facility for listed hazardous/mixed waste even if the waste is treated and the resulting waste form passes the TCLP leaching requirements. An example of this type of waste/waste form is the High Solids Ashcrete and Blowcrete resulting from burning the M-Area Filter Paper Take-up Rolls.

The stabilized waste drums generated in this campaign are stored in M-Area. Off-site disposal at Envirocare is the preferred disposal option. Disposal of Low Solids ashcrete is by trench disposal after waste acceptance have been meet (compression, leaching, permeability).

Currently Portland cement is used to stabilize the incinerator secondary waste. SRS is modifying and upgrading the waste solidification process to optimize solid waste form loadings, improve solid waste form characteristics, increase through put, and reduce equipment down time.

This report details solidification activities using selected Mixed Waste Focus Area (MWFA) technologies with the High and Low Solids waste streams. Ceramicrete ${ }^{\mathrm{TM}}$ and Super Cement ${ }^{\mathrm{TM}}$ technologies were chosen as the best possible replacement solidification candidates for the waste streams generated by the SRS incinerator from a list of several suggested Mixed Waste Focus Area technologies. These technologies were tested, evaluated, and compared to the current Portland cement technology being employed. Recommendation of a technology for replacement depends on waste form performance, process flexibility, process complexity, and cost of equipment and/or raw materials.

Low Solids waste was tested with only Super Cement ${ }^{\mathrm{TM}}$ technology since the Ceramicrete ${ }^{\mathrm{TM}}$ technology had permeability and waste form cracking problems when used in previous High Solids studies. Portland Cement reference samples with High and Low Solids incinerator waste were also generated for comparison with other solid waste form results.

Super Cement ${ }^{\mathrm{TM}}$ technology uses a cement binder of alkali activated slag cement. The cement consists of glassy blast furnace slag, and additives for TCLP improvement, dispersion, and $\mathrm{pH}$ adjustment. Since the Super Cement ${ }^{\mathrm{TM}}$ formulation information is proprietary, specific details will not be released in this report without clearance from the manufacturer, ADTECHS Corp./JGC Corp. 


\section{EXPERIMENTAL METHOD}

Super Cement ${ }^{\mathrm{TM}}$ and Portland cement solid waste forms were made with scrubber solution, ash, and a combination of ash and scrubber solution. All samples were mixed by hand stirring with a spatula in a plastic beaker for 10 minutes. The samples were cast as cylinders with a diameter of approximately $3 \mathrm{~cm}$ and heights varying from about $0.75 \mathrm{~cm}$ to $5 \mathrm{~cm}$. Bleed water observations were conducted during the first three days of curing. After 28 days of curing compression testing was performed with a penetrometer. Samples were then cut from the solid waste forms with a hack saw and sent to an outside laboratory for RCRA metals leach tests.

Characterization data of the High Solids and Low Solids ash and blowdown used to make the solid waste forms are presented in Appendix 1.

\section{Waste Form Acceptance Criteria}

Acceptance criteria for the solid waste forms which include leachability, bleed water, compression testing, and permeability are listed in Tables I, II. Waste loading, mixing properties, and data on whether waste forms meet acceptance criteria will be compared to the current Portland cement solidification technology now used at the SRS incinerator for solidification of waste.

Table I. Acceptance Criteria for Freshly Prepared Waste Forms

$\begin{array}{ll}\text { Property } & \text { Acceptance Criteria } \\ \text { Bleed water } & \text { 0 volume after 24 hours } \\ \text { Set time } & \text { Less than 1 day } \\ \text { Mixability } & \text { low viscosity } \\ \text { Processibility } & \text { Minimal number of components }\end{array}$

Table II. Acceptance Criteria for Cured Waste Forms

Property

Compressive Strength

Permeability

RCRA metal leachability

As

$\mathrm{Hg}$

$\mathrm{Ba}$

$\mathrm{Cr}$

$\mathrm{Pb}$

$\mathrm{Se}$

Ag

$\mathrm{Cd}$

\section{Acceptance Criteria}

$$
>500 \mathrm{psi}
$$$$
<1 \times 10^{-8} \mathrm{~cm} / \mathrm{s}
$$$$
\text { Regulatory Limit (ppm) }
$$

5

0.025

7

0.86

0.37

0.16

0.3

0.69

Note: RCRA metal regulatory leaching ppm limits are from 40CFR 268.48 Universal Treatment Standards. ${ }^{2}$ 
Compressive strength is usually performed by using a mechanical press to crush samples. The amount of force needed to cause the sample to fail is recorded and related to the area. In order to minimize the spread of contamination a method was developed to estimate compressive strength based on resistance to penetration with a Gilson penetrometer.

Waste Processing Technology (WPT) personnel at SRTC were requested to use an ELE Permeameter, which was available in the CIF Laboratory to perform the permeability measurements. This instrument is similar to the one described for ASTM D2434-68. In ASTM D2434-68 a constant low pressure head (constant head test) is used to determine permeability of high permeability materials such as sand or gravel. The ELE instrument is a modified version of this method called a falling head test.

Two non radioactive mixtures were prepared with Portland cement and a 10 and $30 \mathrm{wt} \% \mathrm{NaCl}$ solution for the purpose of learning to use the ELE instrument and to obtain samples to send to UFA Ventures for permeability comparison testing using the centrifuge method. No offsite laboratories were equipped to handle permeability testing of radioactive samples.

The falling head method of determining permeability is based on Darcy's Law. An ELE permeameter, Model K-670A, was used in these experiments. A picture of the permeameter apparatus is given in Figure 1. A technique was developed to glue the diskshaped samples into the ELE sample holder. The apparatus consists of a tank, tank manometer, inlet pressure gauge, outlet pressure gauge, pressure regulator, isolation valves, sample holder, two sample holder heads, connection tubing, and a sample head manometer. Water is forced from the tank through the sample and into a buret at the sample head outlet. The time that it takes to push a known amount of water through the sample is recorded. A schematic of the experimental apparatus is given in Figure 2.

The permeability is calculated using the following equation:

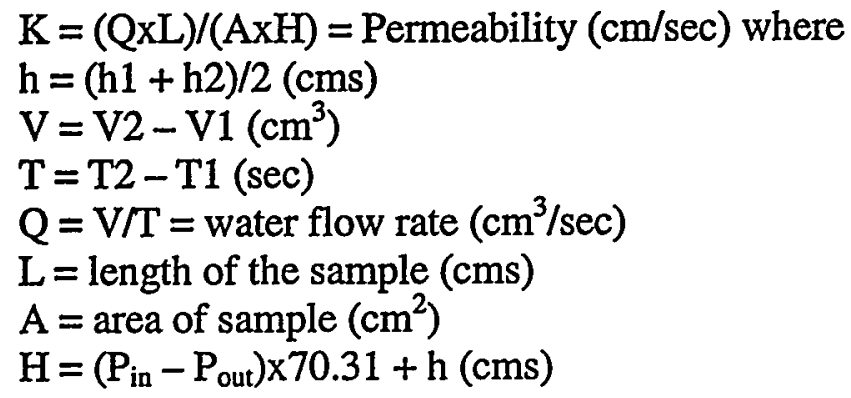

$\mathrm{h} 1$ is the measured distance in centimeters between the top of the tank manometer level and the top of the sample holder manometer when the permeameter is open to the atmosphere before the analysis is performed. $\mathrm{h} 2$ is the measured distance in centimeters between the top of the tank manometer level and the top of the sample holder manometer when the permeameter is open to the atmosphere after the analysis is performed. $V$ is the change in volume of the sample manometer (V2 - V1) from the beginning to the end of time interval, $T=T 2-T 1 . P_{\text {in }}$ and $P_{\text {out }}$ units are pounds per square inch (psi). The 70.31 is a factor to convert psi to centimeters in the $\mathrm{H}$ equation. Appendix 2 contains permeability calculations. 
The permeability results using the Falling Head method were compared to results obtained by UFA Ventures with an open flow Centrifuge method on duplicate samples to verify the accuracy of the Falling Head Method. The centrifuge method is effective because it allows the operator to set the variables in Darcy's Law. Darcy's Law states that the fluid flux equals the permeability times the fluid driving force. The driving force is fixed by imposing an acceleration on the sample through an adjustable rotation speed. The flux is fixed by setting the flow rate into the sample with an appropriate constant flow pump and dispersing the flow front evenly over the sample. Thus, the sample reaches the steady state permeability, which is dictated by that combined flux and driving force.

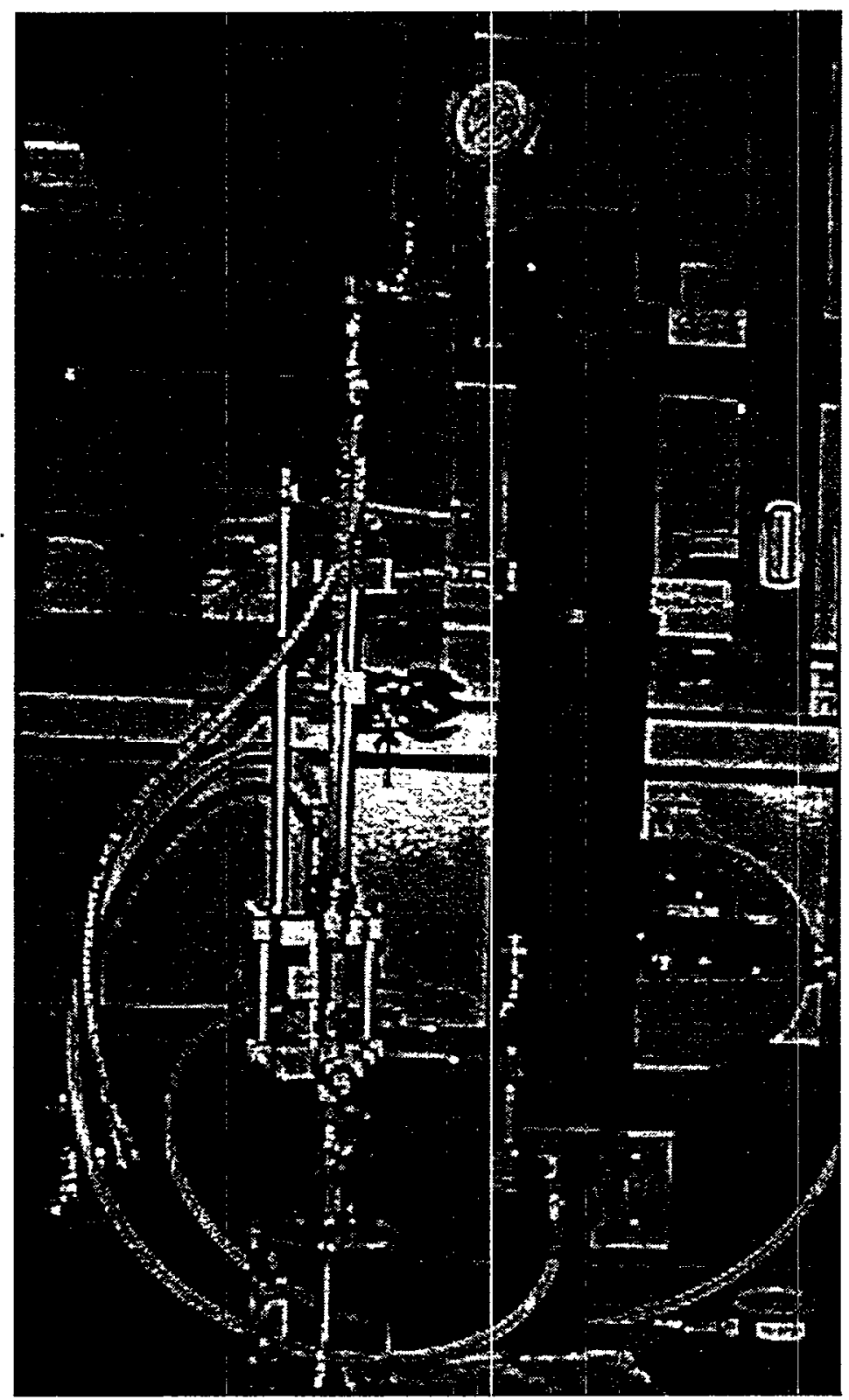

Figure 1. Permeameter manufactured by ELE 


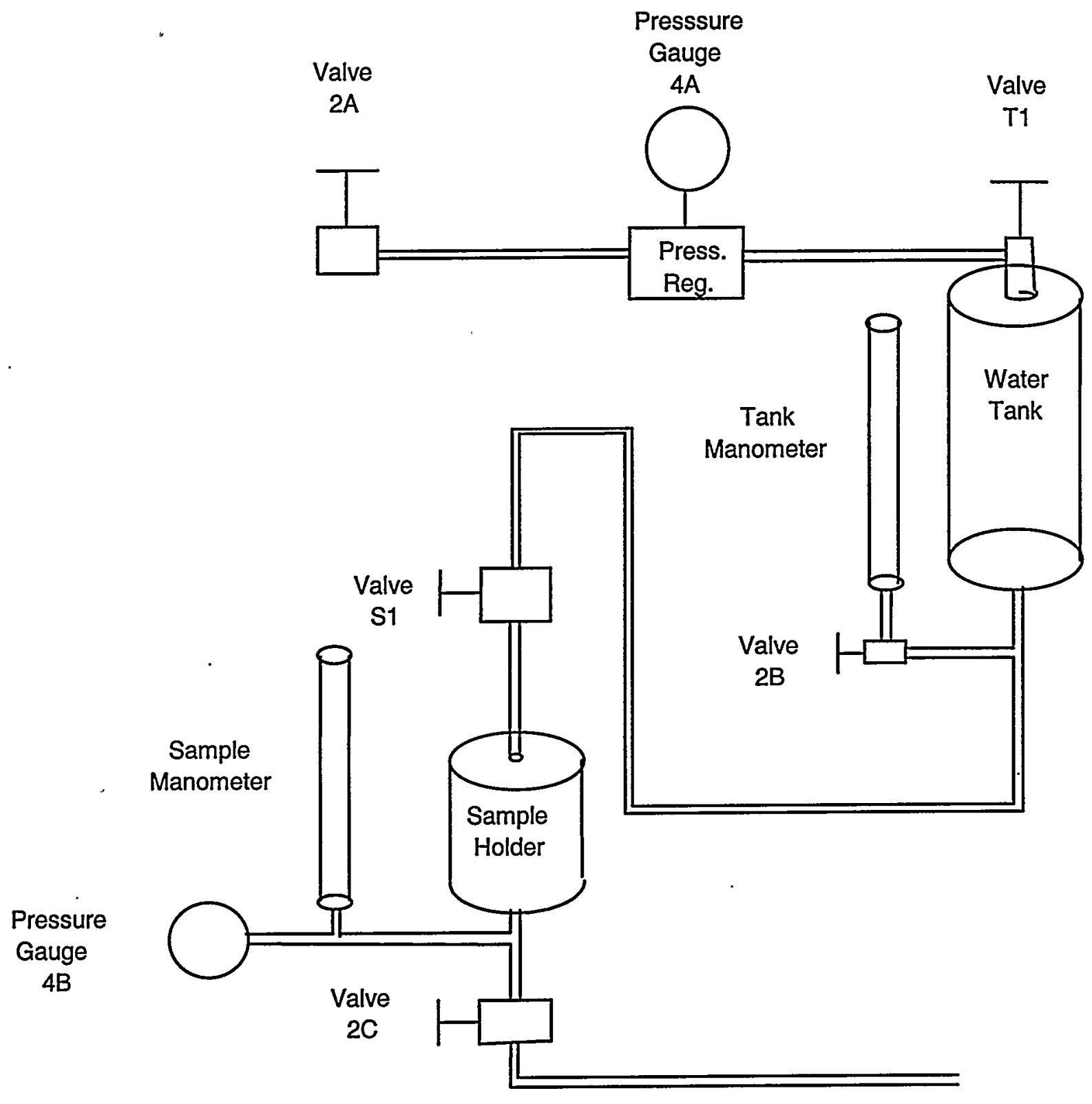

Figure 2. Permeameter Schematic 
A UFA instrument consists of an ultracentrifuge with a constant, ultra-low flow pump that provides fluid to the sample surface through a rotating seal assembly and microdispersal system. The apparatus can reach accelerations of up to $20,000 \mathrm{~g}$, temperatures can be adjusted from - 20 degrees to 150 degrees $C$. Effluent from the sample is collected in a transparent, volumetrically calibrated chamber at the bottom of the sample assembly. A diagram of the centrifuge internal parts is shown in Figure 3 and a picture of the instrument is shown in Figure 4.

\section{Preparation of Super Cement ${ }^{\mathrm{TM}}$ Waste Forms}

Super Cement ${ }^{\mathrm{TM}}$ waste forms were prepared according to Table III and Component Proportions given in Table IV. Super Cement ${ }^{\mathrm{TM}}$ Low Solids waste form compositions are given in Table $\mathrm{V}$ and Component proportions in Table VI. The water to cement ratio ranged from 0.5 to 1 . Details concerning hardening, dispersing, and TMT15 agents are proprietary and will not be disclosed without ADTECHS Corp./JGC Corp. permission. Because the reagent details are proprietary the weight of additives are not listed in any Table in this report.

Sodium sulfide and an organic reagent (TMT15) were added to the initial mix to improve leaching characteristics for toxic metals such as $\mathrm{As}, \mathrm{Se}, \mathrm{Cr}$, and $\mathrm{Pb}$. A dispersing reagent was added to samples containing ash to aid in dispersing the binder particles and fine ash particles.

Super Cement ${ }^{\mathrm{TM}}$ waste form ingredients were mixed for 10 minutes. The sequence of mixing is to:

1) add waste

2) add TMT15 and sodium sulfide

3) add dispersing agent

4) add hardening agent

5) add Super Cement ${ }^{\mathrm{TM}}$.

The Super Cement ${ }^{\mathrm{TM}}$ from Japan by ADTECHS Corp./JGC Corp. containing blended silicon oxide was used in this study.

\section{Preparation of Portland Cement Waste Forms}

Portland cement formulations were determined by an algorithm used by the plant to make solid waste forms. See appendix 3 for plant algorithm information.

Ingredients in the High Solids Portland cement formulations prepared for this study are listed in Table III. The weight per cents of different components in the High Solids formulations are shown in Table IV. Ingredients in the Low Solids Portland cement formulations prepared for this study are listed in Table V. The weight per cents of different components in the Low Solids formulations are shown in Table VI. 


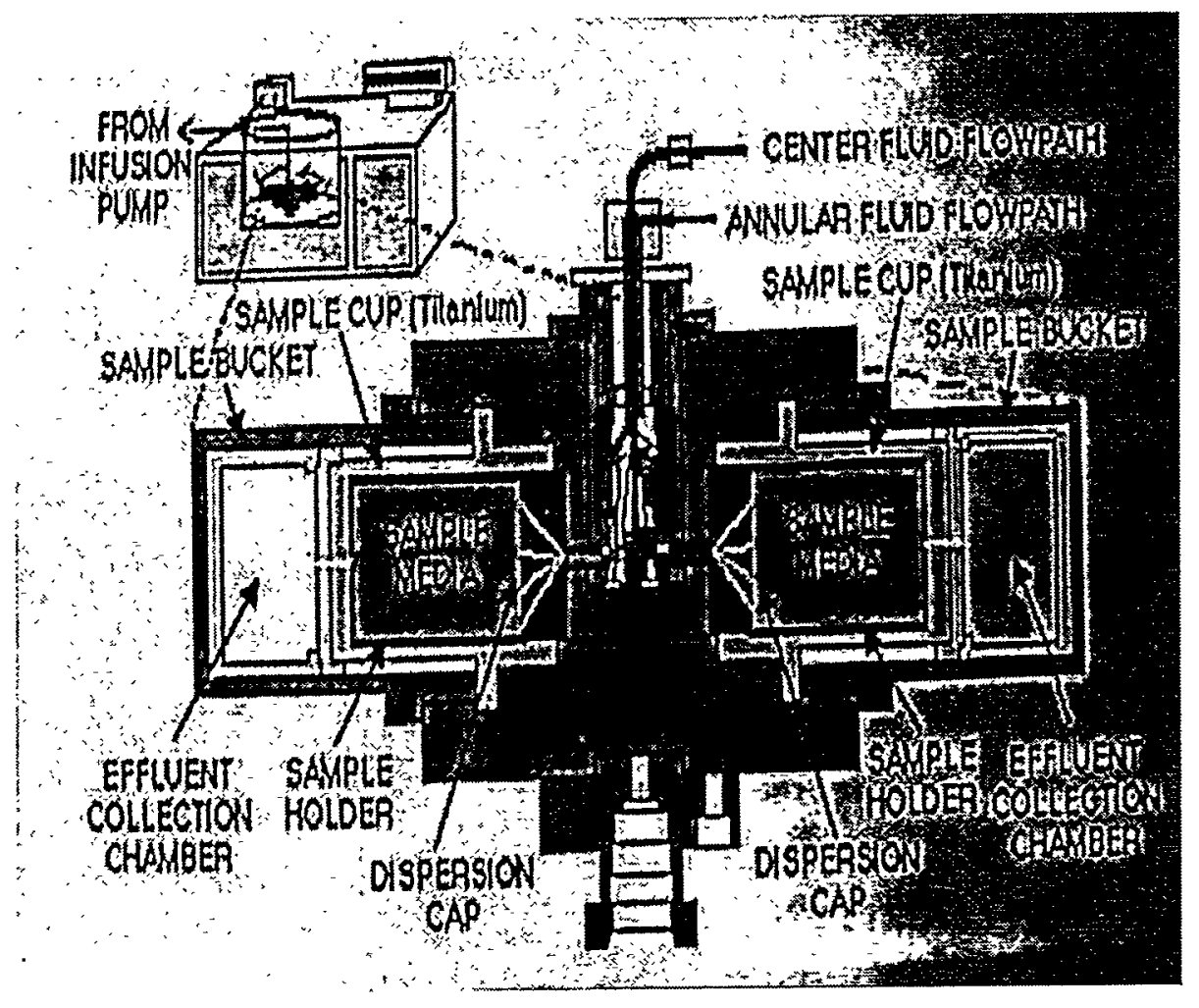

Figure 3. Centrifuge Internal Parts

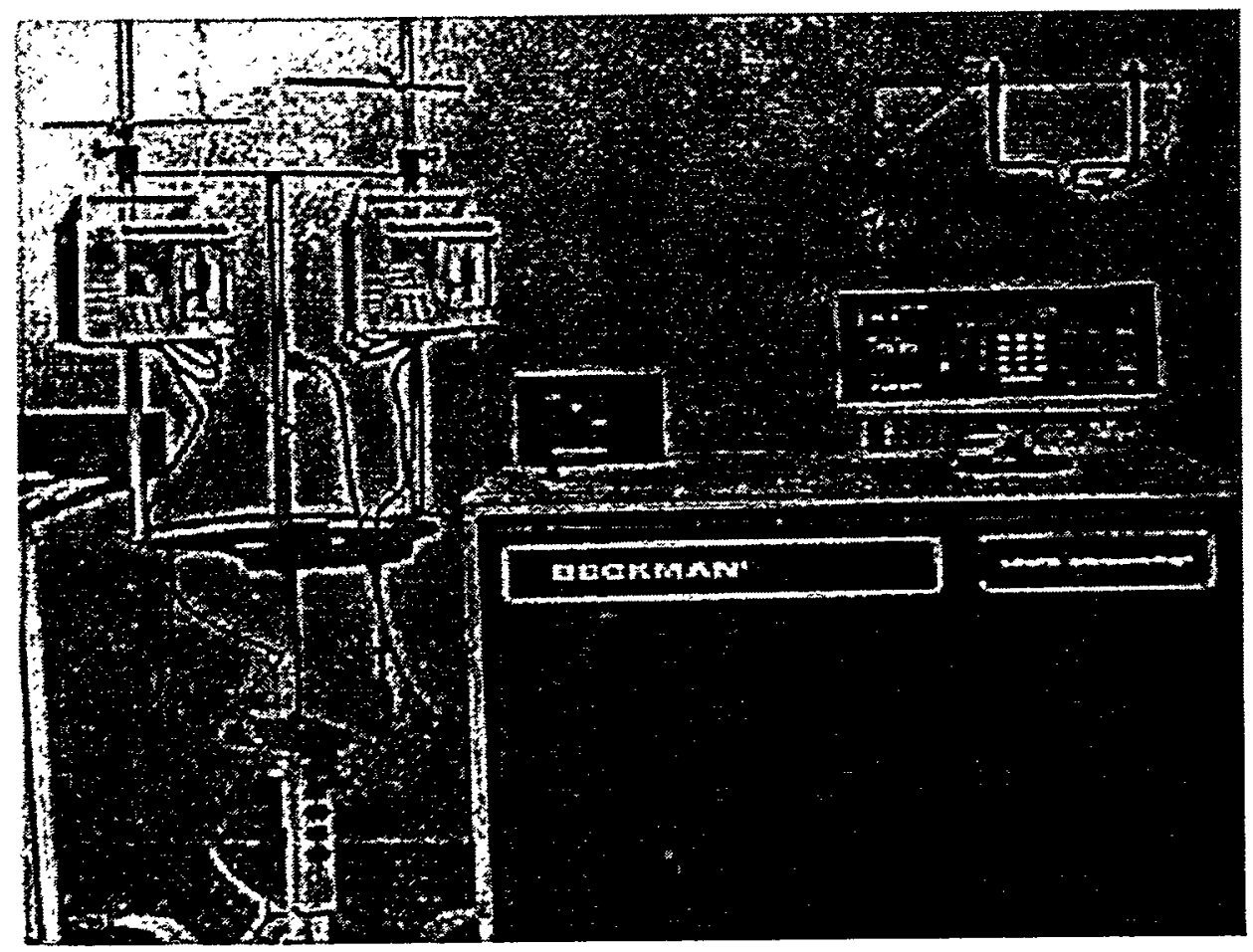

Figure 4. Picture of UFA Centrifuge 
Table III. High Solids Waste Forms Composition

Add. Scrub. Scrub. Scrub.

\begin{tabular}{|c|c|c|c|c|c|c|c|c|}
\hline Sample & $\begin{array}{l}\mathrm{PC} \\
\mathrm{Wt}\end{array}$ & $\begin{array}{l}S C \\
W t\end{array}$ & $\begin{array}{l}\mathrm{H}_{2} \mathrm{O} \\
\mathrm{Wt}\end{array}$ & $\begin{array}{l}\text { Soln. } \\
10 w t \%\end{array}$ & $\begin{array}{l}\text { Soln. } \\
20 w t \%\end{array}$ & $\begin{array}{l}\text { Soln. } \\
\text { 30wt\% }\end{array}$ & $\begin{array}{l}\text { Dry } \\
\text { Ash }\end{array}$ & $\begin{array}{l}\text { Other } \\
\text { Comps }\end{array}$ \\
\hline No. Descrip. & (g) & (g) & $(\mathrm{g})$ & (g) & (g) & (g) & (g) & (g) \\
\hline
\end{tabular}

$1 \quad$ Portland Cem. $86.8 \quad-\quad$ - 40.0 With $10 \mathrm{Wt} \%$

Solids Scrub. Soln.

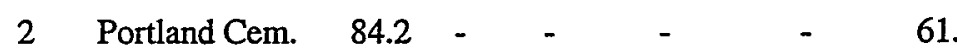
With $30 \mathrm{Wt} \%$

Solids Scrub. Soln.

$\begin{array}{lllllllll}3 & \text { Portland Cem. } & 44.2 & - & 39.8 & - & - & - & 23.8 \\ \text { With ash } & & & & & & & & \end{array}$

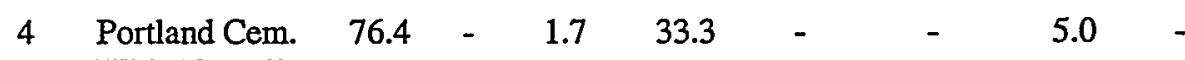

With 10 wt \%

Solids Scrub. Soln.

and ash

$5 \quad$ Portland Cem. $60.2 \quad-\quad 1.7 \quad-\quad \quad \quad-\quad 33.3 \quad 5.0$

\section{With 30 wt \%}

Solids Scrub.

Soln. and ash

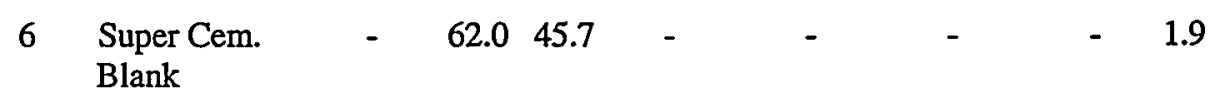

$7 \begin{aligned} & \text { Super Cem. } \\ & 5 \text { wt\% }\end{aligned}$

$5 \mathrm{wt} \% \mathrm{Ca}(\mathrm{OH})_{2}$

$\mathrm{Ca}(\mathrm{OH})_{2}$ mix

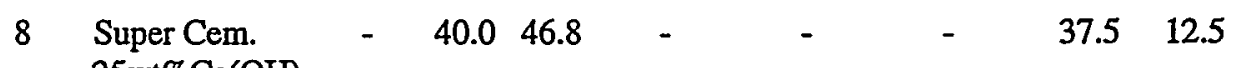

$25 \mathrm{wt} \% \mathrm{Ca}(\mathrm{OH})_{2}$

in ash and

$\mathrm{Ca}(\mathrm{OH})_{2}$ mix

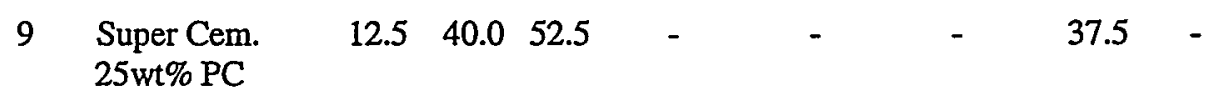

in ash and PC mix

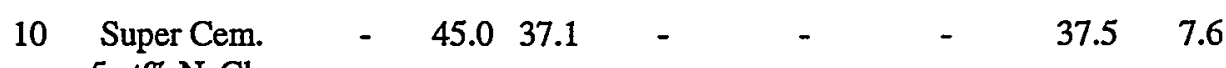
$5 \mathrm{wt} \% \mathrm{NaCl}$

in ash and $\mathrm{NaCl}$ mix 
Table III. High Solids Waste Forms Composition Continued

\begin{tabular}{|c|c|c|c|c|c|c|c|c|c|}
\hline No & $\begin{array}{l}\text { Sample } \\
\text { Descrip. }\end{array}$ & $\begin{array}{l}\text { PC } \\
\text { Wt } \\
(g)\end{array}$ & $\begin{array}{l}S C \\
W t \\
(g)\end{array}$ & $\begin{array}{l}\text { Add } \\
\mathrm{H}_{2} \mathrm{O} \\
W \mathrm{Wt} \\
(\mathrm{g})\end{array}$ & $\begin{array}{l}\text { Scrub. } \\
\text { Soln. } \\
10 w t \% \\
(\mathrm{~g})\end{array}$ & $\begin{array}{l}\text { Scrub. } \\
\text { Soln. } \\
20 w t \% \\
(\mathrm{~g})\end{array}$ & $\begin{array}{l}\text { Scrub. } \\
\text { Soln. } \\
\text { 30wt\% } \\
\text { (g) }\end{array}$ & $\begin{array}{l}\text { Dry } \\
\text { Ash } \\
\text { (g) }\end{array}$ & $\begin{array}{c}\text { Other } \\
\text { Comps } \\
(\mathrm{g})\end{array}$ \\
\hline 11 & $\begin{array}{l}\text { Portland Cem. } \\
10 \text { wt\% } \mathrm{NaCl} \\
\text { simulant }\end{array}$ & 100.0 & - & 41.5 & - & - & - & - & 4.6 \\
\hline 12 & $\begin{array}{l}\text { Portland Cem. } \\
30 \mathrm{wt} \% \mathrm{NaCl} \\
\text { simulant }\end{array}$ & 100.0 & - & 41.5 & - & - & - & - & 17.8 \\
\hline 13 & $\begin{array}{l}\text { Super Cem. } \\
30 \text { wt\% Solids } \\
\text { Scrub. Soln. }\end{array}$ & - & 52.5 & - & - & - & 43.1 & - & 8.5 \\
\hline 14 & $\begin{array}{l}\text { Super Cem. } \\
10 \text { wt\% Solids } \\
\text { Scrub. Soln. }\end{array}$ & - & 56.5 & - & 41.5 & - & - & - & 8.0 \\
\hline
\end{tabular}

Table III notes: 1) The wt \% scrubber solution refer to the concentration of total solids in the solution. 2) Initially the ash contained close to 25 weight $\%$ water. The ash amount is reported in this table on a dry basis and the ash water included in the additional water column. 3) Samples 7,8,9,10 contain a $\%$ of additive to try and improve setting

Table IV. High Solids Waste Form Component Proportions

\begin{tabular}{|c|c|c|c|c|c|c|c|c|}
\hline No. & $\begin{array}{l}\text { Sample } \\
\text { Descrip. }\end{array}$ & $\begin{array}{l}\text { Port. } \\
\text { Cem. } \\
\text { (wt \%) }\end{array}$ & $\begin{array}{l}\text { Sup. } \\
\text { Cem. } \\
\text { wto) }\end{array}$ & $\begin{array}{l}\text { Add. } \\
\text { Water } \\
\text { (wt \%) }\end{array}$ & $\begin{array}{l}\text { S. Soln. } \\
\text { Solids } \\
\text { (wt \%) }\end{array}$ & $\begin{array}{l}\text { Dry } \\
\text { Ash } \\
\text { (wt\%) }\end{array}$ & $\begin{array}{l}\text { Other } \\
\text { Comp. } \\
\text { (wt \%) }\end{array}$ & $\mathrm{W} / \mathrm{C}$ \\
\hline 1 & $\begin{array}{l}\text { Portland Cem. } \\
\text { With } 10 \mathrm{Wt} \% \\
\text { Solids Scrub. Sol }\end{array}$ & $\begin{array}{l}68.4 \\
\text { ln. }\end{array}$ & - & - & 31.6 & - & - & 0.42 \\
\hline 2 & $\begin{array}{l}\text { Portland Cem. } \\
\text { With } 30 \mathrm{Wt} \% \\
\text { Solids Scrub. Sol }\end{array}$ & $\begin{array}{l}58.0 \\
\text { In. }\end{array}$ & - & - & 42.0 & - & - & 0.51 \\
\hline 3 & $\begin{array}{l}\text { Portland Cem. } \\
\text { With ash }\end{array}$ & 41.0 & - & 36.9 & - & 22.1 & - & 0.90 \\
\hline 4 & $\begin{array}{l}\text { Portland Cem. } \\
\text { With } 10 \text { wt \% } \\
\text { Solids Scrub. Sol } \\
\text { and ash }\end{array}$ & 65.6 & - & 1.5 & 28.6 & 4.3 & - & 0.46 \\
\hline
\end{tabular}


Table IV. High SolidsWaste Form Component Proportions Continued

\begin{tabular}{|c|c|c|c|c|c|c|c|c|}
\hline & $\begin{array}{c}\text { Sample } \\
\text { Descrip. } \\
\end{array}$ & $\begin{array}{l}\text { Port. } \\
\text { Cem. } \\
\text { (wt \%) }\end{array}$ & $\begin{array}{l}\text { Sup. } \\
\text { Cem. } \\
\text { wt\%) }\end{array}$ & $\begin{array}{l}\text { Add. } \\
\text { Water } \\
\text { (wt \%) } \\
\end{array}$ & $\begin{array}{l}\text { S. Soln } \\
\text { Solids } \\
\text { (wt \%) }\end{array}$ & $\begin{array}{l}\text { Dry } \\
\text { Ash } \\
\text { (wt\%) }\end{array}$ & $\begin{array}{l}\text { Other } \\
\text { Comp. } \\
\text { (wt \%) }\end{array}$ & $\mathrm{W} / \mathrm{C}$ \\
\hline 5 & $\begin{array}{l}\text { Portland Cem. } \\
\text { With } 30 \text { wt \% } \\
\text { Solids Scrub. Sol } \\
\text { And ash }\end{array}$ & 60.1 & - & 1.7 & 33.2 & 5.0 & - & 0.42 \\
\hline 6 & $\begin{array}{l}\text { Super Cem. } \\
\text { Blank }\end{array}$ & - & 56.6 & 41.7 & - & - & 1.7 & 0.74 \\
\hline 7 & $\begin{array}{l}\text { Super Cem. } \\
5 \mathrm{wt} \% \mathrm{Ca}(\mathrm{OH})_{2} \\
\text { in ash and } \\
\mathrm{Ca}(\mathrm{OH})_{2} \text { mix }\end{array}$ & - & 37.7 & 32.1 & - & 28.3 & 1.9 & 0.85 \\
\hline 8 & $\begin{array}{l}\text { Super } \mathrm{Cem} \text {. } \\
25 \mathrm{wt} \% \mathrm{Ca}(\mathrm{OH})_{2} \\
\text { in ash and } \\
\mathrm{Ca}(\mathrm{OH})_{2} \text { mix }\end{array}$ & - & 29.2 & 34.2 & - & 27.4 & 9.2 & 1.2 \\
\hline 9 & $\begin{array}{l}\text { Super Cem. } \\
25 w t \% \text { PC } \\
\text { in ash and PC mi }\end{array}$ & 8.8 & 28.1 & 36.8 & - & 26.3 & - & 1.0 \\
\hline 10 & $\begin{array}{l}\text { Super Cem. } \\
5 \text { wt\% } \mathrm{NaCl} \\
\text { in ash and } \mathrm{NaCl}\end{array}$ & iix & 35.4 & 29.2 & - & 29.5 & 5.9 & 0.82 \\
\hline 11 & $\begin{array}{l}\text { Portland Cem. } \\
10 \mathrm{wt} \% \mathrm{NaCl} \\
\text { simulant }\end{array}$ & 68.4 & - & 28.4 & - & - & 3.2 & 0.42 \\
\hline 12 & $\begin{array}{l}\text { Portland Cem. } \\
30 \text { wt\% } \mathrm{NaCl} \\
\text { simulant }\end{array}$ & 62.8 & - & 26.0 & - & - & 11.2 & 0.42 \\
\hline 13 & $\begin{array}{l}\text { Super Cem. } \\
30 \text { wt } \% \text { Solids } \\
\text { Scrub. Soln. }\end{array}$ & - & 50.4 & - & 41.4 & - & 8.2 & 0.57 \\
\hline 14 & $\begin{array}{l}\text { Super Cem. } \\
10 \text { wt\% Solids } \\
\text { Scrub. Soln. }\end{array}$ & - & 53.3 & - & 39.2 & - & 7.5 & 0.66 \\
\hline
\end{tabular}

Table IV notes: 1) The wt $\%$ scrubber solution refers to the concentration of total solids in the solution. 2) Initially the ash contained close to 25 weight $\%$ water. The ash amount is reported in this table on a dry basis and the ash water included in the water column. 3) W/C is water to cement ratio 
Table V. Low Solids Waste Forms Composition

Add. Scrub. Scrub. Scrub. Scrub. Scrub.

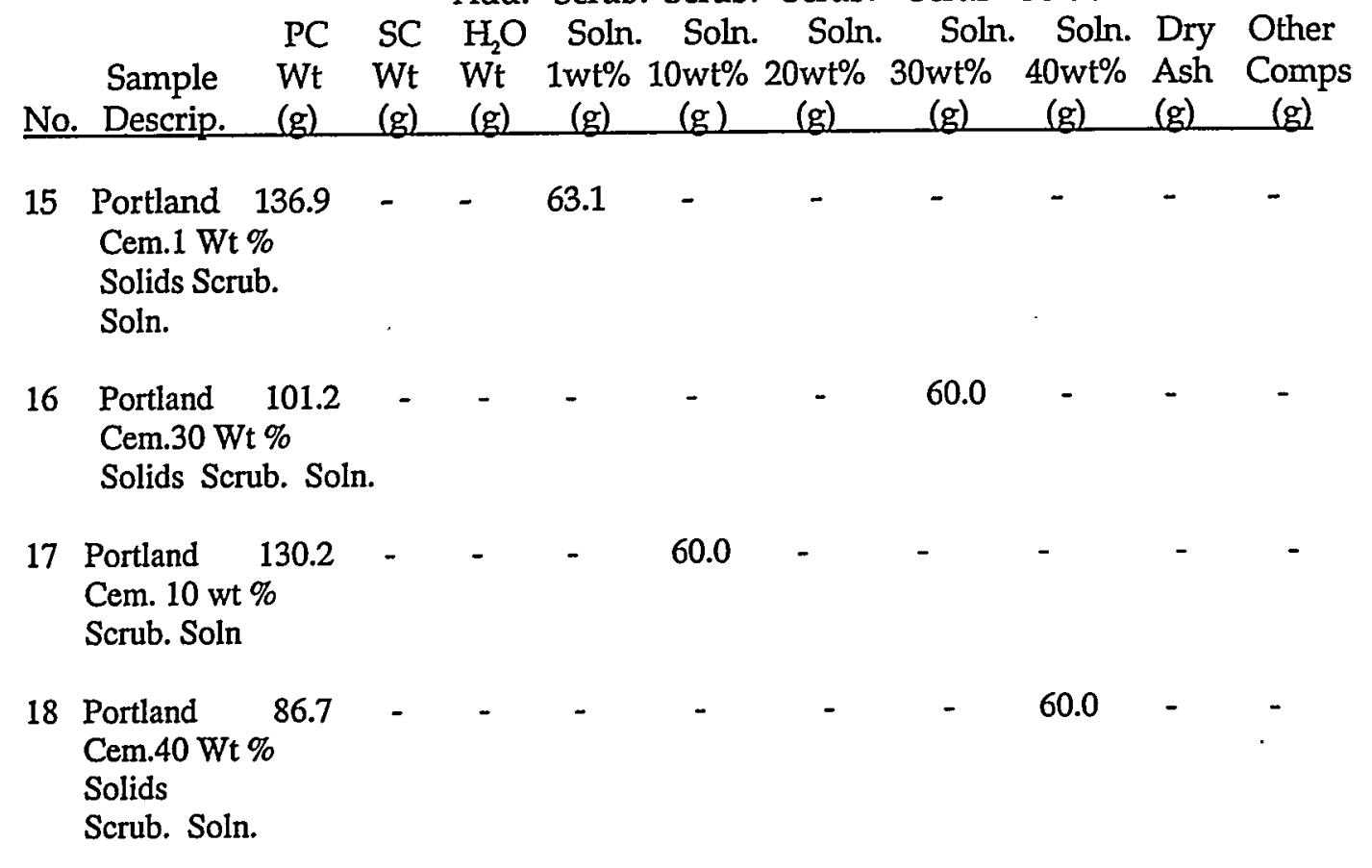

19 Portland 77.5

Cem.

with wet ash

Cem.

with wet ash

21 Portland 225

Cem. Plant

Ashcrete

22 Super

Cem.20

wt \% Solids

Scrub. Soln.

23 Super

81.7

77.0

60.0

11.8

Cem.10

wt \% Solids

Scrub. Soln. 
Table V. Low Solids Waste Forms Composition Continued

Add. Scrub. Scrub. Scrub. Scrub. Scrub.

\begin{tabular}{|c|c|c|c|c|c|c|c|c|c|c|c|}
\hline No & $\begin{array}{l}\text { Sample } \\
\text { Descrip. }\end{array}$ & $\begin{array}{l}P C \\
W t \\
(g)\end{array}$ & $\begin{array}{l}S C \\
W t \\
(g)\end{array}$ & $\begin{array}{l}\mathrm{H}_{2} \mathrm{O} \\
\mathrm{Wt} \\
(\mathrm{g})\end{array}$ & $\begin{array}{l}\text { Soln. } \\
1 \text { wt } \% \\
\text { (g) }\end{array}$ & $\begin{array}{l}\text { Soln. } \\
10 \mathrm{wt} \% \\
\text { (g) }\end{array}$ & $\begin{array}{l}\text { Soln. } \\
20 w t \% \\
\text { (g) }\end{array}$ & $\begin{array}{l}\text { Soln. } \\
30 w t \% \\
(\mathrm{~g})\end{array}$ & $\begin{array}{l}\text { Soln. } \\
40 w t \% \\
\text { (g) }\end{array}$ & $\begin{array}{l}\text { Dry } \\
\text { Ash } \\
\text { (g) }\end{array}$ & $\begin{array}{l}\text { Other } \\
\text { Comps } \\
\text { (g) }\end{array}$ \\
\hline 24 & $\begin{array}{l}\text { Super } \\
\text { Cem. } 30 \\
\text { wt \% Solids } \\
\text { Scrub. Soln. }\end{array}$ & - & 73.1 & - & - & - & - & 60.0 & - & - & 11.9 \\
\hline 25 & $\begin{array}{l}\text { Super } \\
\text { Cem.40 } \\
\text { wt \% Solids } \\
\text { Scrub. Soln. }\end{array}$ & - & 72.3 & - & - & - & - & - & 60.0 & - & 12.0 \\
\hline 26 & $\begin{array}{l}\text { Super } \\
\text { Cem. } \\
\text { lwt \% Solids } \\
\text { Scrub. Soln. }\end{array}$ & - & 62.0 & - & 40.0 & - & - & - & - & - & 8.0 \\
\hline 27 & $\begin{array}{l}\text { Super Cem. } \\
\text { Wet Ash with } \\
\text { Setting agent }\end{array}$ & - & 40.0 & 12.5 & - & - & - & - & - & 37.5 & 17.1 \\
\hline 28 & $\begin{array}{l}\text { Super Cem. } \\
\text { Wet Ash } \\
\text { no setting age }\end{array}$ & - & 40.0 & 15.0 & - & - & - & - & - & 45.0 & 11.8 \\
\hline
\end{tabular}

Table V notes: 1) Wt \% scrubber solution refer to the concentration of total solids in the solution. 2) Initially the ash contained close to 25 weight $\%$ water. The ash amount is reported in this table on a dry basis and the ash water included in the additional water column.

Table VI. Low Solids Waste Form Component Proportions

\begin{tabular}{|c|c|c|c|c|c|c|c|c|}
\hline No. & $\begin{array}{l}\text { Sample } \\
\text { Descrip. }\end{array}$ & $\begin{array}{l}\text { Port. } \\
\text { Cem. } \\
\text { (wt \%) }\end{array}$ & $\begin{array}{l}\text { Sup. } \\
\text { Cem. } \\
w t \%)\end{array}$ & $\begin{array}{l}\text { Add. } \\
\text { Water } \\
\text { (wt \%) }\end{array}$ & $\begin{array}{l}\text { S. Soln. } \\
\text { Solids } \\
\text { (wt \%) }\end{array}$ & $\begin{array}{l}\text { Dry } \\
\text { Ash } \\
\text { (wt\%) }\end{array}$ & $\begin{array}{l}\text { Other } \\
\text { Comp. } \\
\text { (wt \%) }\end{array}$ & $W / C$ \\
\hline 15 & $\begin{array}{l}\text { Portland } \\
\text { Cem.1 Wt \% } \\
\text { Solids Scrub. Sol }\end{array}$ & 68.5 & - & - & 31.5 & - & - & 0.44 \\
\hline 16 & $\begin{array}{l}\text { Portland Cem. } \\
\text { With } 30 \mathrm{Wt} \% \\
\text { Solids Scrub. Sol }\end{array}$ & 62.8 & - & - & 37.2 & - & - & 0.40 \\
\hline 17 & $\begin{array}{l}\text { Portland } \\
\text { Cem. } 10 \text { wt \% } \\
\text { Scrub. Soln }\end{array}$ & 68.5 & - & - & - & 31.6 & - & 0.40 \\
\hline
\end{tabular}


Table VI. Low Solids Waste Form Component Proportions Continued

\begin{tabular}{|c|c|c|c|c|c|c|c|c|}
\hline No. & $\begin{array}{l}\text { Sample } \\
\text { Descrip. }\end{array}$ & $\begin{array}{l}\text { Port. } \\
\text { Cem. } \\
\text { (wt \%) }\end{array}$ & $\begin{array}{l}\text { Sup. } \\
\text { Cem. } \\
\text { (wt\%) }\end{array}$ & $\begin{array}{l}\text { Add. } \\
\text { Water } \\
\text { (wt \%) }\end{array}$ & $\begin{array}{l}\text { S. Soln. } \\
\text { Solids } \\
\text { (wt \%) }\end{array}$ & $\begin{array}{l}\text { Dry } \\
\text { Ash } \\
\text { (wt\%) }\end{array}$ & $\begin{array}{l}\text { Other } \\
\text { Comp. } \\
\text { (wt \%) }\end{array}$ & W/C \\
\hline 18 & $\begin{array}{l}\text { Portland } \\
\text { Cem. 40wt } \\
\text { Scrub. Soln }\end{array}$ & 59.1 & - & - & 40.9 & - & - & 0.47 \\
\hline 19 & $\begin{array}{l}\text { Portland Cem. } \\
\text { With wet ash }\end{array}$ & 38.7 & - & 40.4 & - & 20.9 & - & 1.04 \\
\hline 20 & $\begin{array}{l}\text { Portland } \\
\text { Cem. } \\
\text { with wet ash }\end{array}$ & 53.3 & - & 30.7 & - & 15.9 & - & 0.58 \\
\hline 21 & $\begin{array}{l}\text { Portland } \\
\text { Cem. Plant } \\
\text { Ashcrete }\end{array}$ & 55.2 & - & 41.2 & - & 3.5 & - & 0.75 \\
\hline 22 & $\begin{array}{l}\text { Super Cem. } \\
\text { With } 20 \text { wt \% } \\
\text { Solids Scrub. Soln. }\end{array}$ & - & 51.8 & - & 40.3 & - & 7.9 & 0.62 \\
\hline 23 & $\begin{array}{l}\text { Super Cem. } \\
\text { With } 10 \mathrm{wt} \% \\
\text { Solids Scrub. Soln. }\end{array}$ & - & 53.3 & - & 39.1 & - & 7.6 & 0.66 \\
\hline 24 & $\begin{array}{l}\text { Super Cem. } \\
30 \text { wt } \% \\
\text { Solids Scrub. Soln. }\end{array}$ & - & 50.4 & - & 41.4 & - & 8.2 & 0.58 \\
\hline 25 & $\begin{array}{l}\text { Super Cem. } \\
40 w t \% \text { Solids } \\
\text { Scrub. Soln. }\end{array}$ & - & 50.1 & - & 41.6 & - & 8.3 & 0.50 \\
\hline 26 & $\begin{array}{l}\text { Super Cem. } \\
\text { 1wt\% Solids } \\
\text { Scrub. Soln. }\end{array}$ & - & 56.4 & - & 36.4 & - & 7.2 & 0.64 \\
\hline 27 & $\begin{array}{l}\text { Super Cem. } \\
\text { Wet Ash with } \\
\text { setting agent }\end{array}$ & - & 37.4 & 11.7 & - & 35.0 & 16.0 & 0.31 \\
\hline 28 & $\begin{array}{l}\text { Super Cem. } \\
\text { Wet Ash no } \\
\text { setting agent }\end{array}$ & - & 35.8 & 13.4 & - & 40.3 & 10.6 & 0.37 \\
\hline
\end{tabular}


Table VI notes: 1) Scrubber solution solids refers to the concentration of total solids in the solution. 2) Initially the ash contained close to 25 weight $\%$ water. The ash amount is reported in this table on a dry basis and the ash water included in the water column.

3) W/C is water to cement ratio

\section{RESULTS}

\section{Processing Properties}

High Solids Super Cement ${ }^{\mathrm{TM}}$ Processing Properties are given in Table VII.

Table VII. High Solids Super Cement ${ }^{\mathrm{TM}}$ Processing Properties Evaluation

\begin{tabular}{|c|c|c|c|c|}
\hline Waste form Type & $\begin{array}{l}\text { Set Time } \\
\leq 1 \text { day }\end{array}$ & $\begin{array}{l}\text { Bleedwater } \\
\text { after } 24 \mathrm{hrs} \text {. }\end{array}$ & $\begin{array}{l}\text { Good } \\
\text { Mixability }\end{array}$ & $\begin{array}{l}\text { Easily } \\
\text { Processed }\end{array}$ \\
\hline Ash & no & no & yes & yes \\
\hline Scrubber solution & yes & no & yes & yes \\
\hline $\begin{array}{l}\text { Ash and scrubber } \\
\text { solution }\end{array}$ & yes & no & yes & yes \\
\hline Modified Ash & yes & no & yes & yes \\
\hline
\end{tabular}

Super Cement ${ }^{\mathrm{TM}}$ High Solids waste forms made from only scrubber solution and a ashscrubber solution combination using the original formulation set within 24 hours. Waste forms made with only ash using the original formulation did not set after 24 hours.

The formulation modification of adding enough calcium hydroxide to the ash so that the calcium hydroxide is $25 \mathrm{wt} \%$ of the ash and calcium hydroxide mixture then treating with Super Cement ${ }^{\mathrm{TM}}$ resulted in a waste form that set within time requirements. Use of only $5 \%$ by weight calcium hydroxide with ash and calcium hydroxide mixture and Super Cement ${ }^{\mathrm{TM}}$ treatment did not give a waste form that set within time requirements.

Formulation modification by adding Portland cement to the ash so the Portland cement is $25 \%$ by weight of the Portland Cement and ash mixture followed by Super Cement ${ }^{\mathrm{TM}}$ treatment also gave waste forms that set with time constraints. The modification of adding $25 \%$ by weight of $\mathrm{NaCl}$ in an ash and $\mathrm{NaCl}$ mixture then Super Cement ${ }^{\mathrm{TM}}$ treatment resulted in a waste form that did not set.

Low Solids Super Cement ${ }^{\mathrm{TM}}$ Processing Properties are given in Table VIII. 
Table VIII. Low Solids Super Cement ${ }^{\mathrm{TM}}$ Processing Properties Evaluation

\begin{tabular}{|c|c|c|c|c|}
\hline Waste form Type & $\begin{array}{l}\text { Set Time } \\
<1 \text { day }\end{array}$ & $\begin{array}{l}\text { Bleedwater } \\
\text { after } 24 \mathrm{hrs} \text {. }\end{array}$ & $\begin{array}{l}\text { Good } \\
\text { Mixability }\end{array}$ & $\begin{array}{l}\text { Easily } \\
\text { Processed }\end{array}$ \\
\hline$\overline{\text { Ash }}$ & yes & no & yes & yes \\
\hline Scrubber solution & yes & no & yes & yes \\
\hline $\begin{array}{l}\text { Ash and scrubber } \\
\text { solution }\end{array}$ & yes & no & yes & yes \\
\hline Modified Ash & yes & no & yes & yes \\
\hline
\end{tabular}

Note: A bleed water problem was observed with the Low Solids Portland cement ash waste forms made for comparison testing but not in the Low Solids Super Cement ash waste forms.

\section{Cured Waste Form Properties}

Compressive strength estimates were determined after 28 days of curing time by using a Penetrometer for Concrete model \# HM-78 from the Gilson Company in Worthington, Ohio.

Compressive strengths of High Solids Super Cement ${ }^{\mathrm{TM}}$ waste forms made with scrubber solutions and a combination of scrubber solutions and ash were $>700 \mathrm{psi}$ which meets acceptance criteria. High Solids Super Cement ${ }^{\mathrm{TM}}$ waste forms made with ash using the original formulation gave unacceptable compression results of $<500 \mathrm{psi}$ but waste forms made with calcium hydroxide reagent pass compression requirements.

High Solids Super Cement ${ }^{\mathrm{TM}}$ cured properties are listed in Table IX.

Table IX. High Solids Super Cement ${ }^{\mathrm{TM}}$ Cured Properties Evaluation

$$
>500 \mathrm{psi} \quad<1 \times 10^{-8} \mathrm{~cm} / \mathrm{s} \text { Leachability }
$$

Waste form Type Compressibility permeability limits met

Blank waste form yes yes not applicable

Ash no yes yes

Scrubber solution yes no yes

Ash and scrubber yes not tested yes solution

Modified Ash

yes

no

yes 
Compressive strengths of Low Solids Super Cement ${ }^{\mathrm{TM}}$ waste forms made with scrubber solutions and a combination of scrubber solutions and ash were $>700$ psi which meets acceptance criteria. Waste forms made with ash using the original formulation also gave acceptable compression results of $>700$ psi.

Table X. Low Solids Super Cement ${ }^{\mathrm{TM}}$ Cured Waste Form Criteria Evaluation

$\begin{array}{lll}\text { Waste form Type } & \begin{array}{l}>500 \mathrm{psi} \\ \text { Compressibility }\end{array} & <1 \times 10^{-8} \mathrm{~cm} / \mathrm{s} \text { Leachability } \\ \text { permeability limits met }\end{array}$

\begin{tabular}{|c|c|c|}
\hline Ash, no $\mathrm{Ca}(\mathrm{OH})_{2}$ & yes & no \\
\hline Scrubber solution & yes & no \\
\hline $\begin{array}{l}\text { Ash and scrubber } \\
\text { solution }\end{array}$ & yes & not tested \\
\hline Ash, with $\mathrm{Ca}(\mathrm{OH})_{2}$ & yes & yes \\
\hline
\end{tabular}

Permeability Results

Two non radioactive mixtures were prepared with Portland cement and a 10 and $30 \mathrm{wt} \%$ $\mathrm{NaCl}$ solution for the purpose of learning to use the ELE instrument and to obtain samples to send to UFA Ventures for permeability testing using the centrifuge method. These formulations were cast into several sample containers which were sealed for curing.

The non radioactive simulant samples made with 10 and $30 \mathrm{wt} \% \mathrm{NaCl}$ were used to establish a correlation between the falling head and whole body centrifuge permeability results. Results obtained by the centrifuge method were one order of magnitude higher (10x more permeable) than those obtained by the falling head method. This correlation was used to estimate centrifuge permeability results because radioactive samples could not be analyzed using this method. Therefore in Tables XI through XIV the falling head permeability values were measured and the centrifuge permeability values were calculated. Since the centrifuge method is the worst case scenario it was decided to use the predicted centrifuge results in determining whether samples met permeability acceptance criteria.

Permeabilities of High Solids Portland cement sample were determined for comparison with High Solids Super cement sample permeabilities and are given in Table XI.

The highest High Solids blowdown concentration that can be stabilized with Portland cement is $10 \mathrm{wt} \%$ total solids. High Solids ash stabilized with Portland cement gives a centrifuge permeability which meets SRS acceptance requirements. 
Table XI. High Solids Portland Cement Waste Form Permeabilities

\begin{tabular}{|c|c|c|c|c|c|}
\hline $\begin{array}{l}\text { Sample } \\
\text { Number }\end{array}$ & $\begin{array}{l}\text { Sample } \\
\text { Description }\end{array}$ & $\begin{array}{l}\text { Falling Head } \\
\text { Permeability } \\
(\mathrm{cm} / \mathrm{s}) \\
\end{array}$ & $\begin{array}{l}\text { E-Area } \\
\text { WAC }\end{array}$ & $\begin{array}{l}\text { Est. Centrif. } \\
\text { Permeability } \\
(\mathrm{cm} / \mathrm{s})\end{array}$ & $\begin{array}{l}\text { E-Area } \\
\text { WAC }\end{array}$ \\
\hline 11 & $\begin{array}{l}\text { Simulant } \\
\text { with } 10 \text { wt \% } \\
\mathrm{NaCl} \text { solution }\end{array}$ & $<1.7 \times 10^{-10}$ & Pass & $1.7 \times 10^{-9}$ & $\begin{array}{l}\text { Projected } \\
\text { Pass }\end{array}$ \\
\hline 12 & $\begin{array}{l}\text { Simulant } \\
\text { with } 30 \text { wt \% } \\
\mathrm{NaCl} \text { solution }\end{array}$ & $2.9 \times 10^{-9}$ & Pass & $3.1 \times 10^{-8}$ & $\begin{array}{l}\text { Projected } \\
\text { Fail }\end{array}$ \\
\hline 1 & $\begin{array}{l}\text { blowcrete } \\
\text { with } 10 \text { wt } \% \\
\text { solids scrub. solutio }\end{array}$ & $\begin{array}{l}6.2 \times 10^{-10} \\
\text { on }\end{array}$ & Pass & $6.2 \times 10^{-9}$ & $\begin{array}{l}\text { Projected } \\
\text { Pass }\end{array}$ \\
\hline 2 & $\begin{array}{l}\text { blowcrete } \\
\text { with } 30 \text { wt \% } \\
\text { solids scrub. solutio }\end{array}$ & $7.5 \times 10^{-9}$ & Pass & $7.5 \times 10^{-8}$ & $\begin{array}{l}\text { Projected } \\
\text { Fail }\end{array}$ \\
\hline
\end{tabular}

$\begin{array}{lllll}6.2 \times 10^{-10} & \text { Pass } & 6.2 \times 10^{-9} & \begin{array}{l}\text { Projected } \\ \text { Pass }\end{array}\end{array}$

High Solids Super cement sample permeabilities are given in Table XII.

Table XII. High Solids Super Cement Waste Form Permeabilities

\begin{tabular}{|c|c|c|c|c|c|}
\hline $\begin{array}{l}\text { Sample } \\
\text { Numbe }\end{array}$ & $\begin{array}{l}\text { Sample } \\
\text { Description }\end{array}$ & $\begin{array}{l}\text { Falling Head } \\
\text { Permeability } \\
\text { (cm/s) }\end{array}$ & $\begin{array}{c}\text { E-Area } \\
\text { WAC }\end{array}$ & $\begin{array}{l}\text { Est. Centrif. } \\
\text { Permeability } \\
(\mathrm{cm} / \mathrm{s})\end{array}$ & $\begin{array}{l}\text { E-Area } \\
\text { WAC }\end{array}$ \\
\hline 8 & $\begin{array}{l}\text { ashcrete } \\
25 \mathrm{wt} \% \mathrm{Ca}(\mathrm{OH})_{2} \text { in } \\
\text { ash and } \mathrm{Ca}(\mathrm{OH})_{2} \text { mix }\end{array}$ & $4.8 \times 10^{-9}$ & Pass & $4.8 \times 10^{-8}$ & $\begin{array}{l}\text { Projected } \\
\text { Fail }\end{array}$ \\
\hline 13 & $\begin{array}{l}\text { blowcrete } \\
\text { with } 30 \text { wt } \% \\
\text { solids scrub. solutic }\end{array}$ & $\begin{array}{l}4.6 \times 10^{-7} \\
\text { on }\end{array}$ & Fail & $4.6 \times 10^{-6}$ & $\begin{array}{l}\text { Projected } \\
\text { Fail }\end{array}$ \\
\hline 14 & $\begin{array}{l}\text { blowcrete } \\
\text { with } 10 \text { wt } \% \\
\text { solids scrub. solutic }\end{array}$ & $8.0 \times 10^{-7}$ & \multicolumn{2}{|c|}{ Unknown $8.0 \times 10^{-6}$} & Unknown \\
\hline
\end{tabular}

Centrifuge permeabilities for High Solids Super Cement waste forms made with ash and blowdown at $30 \mathrm{wt} \%$ concentrations do not meet SRS requirements. Sample 14 seemed 
to be cracked which could give an erroneous permeability value.

Low Solids Portland Cement permeability test results are summarized in Table XIII:

Table XII. Low Solids Portland Cement Waste Form Permeabilities

\begin{tabular}{|c|c|c|c|c|c|}
\hline $\begin{array}{l}\text { Sample } \\
\text { Numbe }\end{array}$ & $\begin{array}{l}\text { Sample } \\
\text { Description } \\
\end{array}$ & $\begin{array}{l}\text { Falling Head } \\
\text { Permeability } \\
(\mathrm{cm} / \mathrm{s})\end{array}$ & $\begin{array}{l}\text { E-Area } \\
\text { WAC }\end{array}$ & $\begin{array}{l}\text { Est. Centrif. } \\
\text { Permeability } \\
(\mathrm{cm} / \mathrm{s})\end{array}$ & $\begin{array}{l}\text { E-Area } \\
\text { WAC }\end{array}$ \\
\hline 15 & $\begin{array}{l}\text { Purex blow } \\
\text { crete with } 1 \text { wt } \% \\
\text { solids scrub. solution }\end{array}$ & $2.0 \times 10^{-9}$ & Pass & $2.0 \times 10^{-8}$ & $\begin{array}{l}\text { Projected } \\
\text { Fail }\end{array}$ \\
\hline 18 & $\begin{array}{l}\text { Purex blow } \\
\text { crete with } 40 \text { wt } \% \\
\text { solids scrub. solution }\end{array}$ & $8.5 \times 10^{-9}$ & Pass & $8.5 \times 10^{-8}$ & $\begin{array}{l}\text { Projected } \\
\text { Fail }\end{array}$ \\
\hline 19 & Purex ashcrete & $<4.2 \times 10^{-10}$ & Pass & $<4.2 \times 10^{-9}$ & $\begin{array}{l}\text { Projected } \\
\text { Pass }\end{array}$ \\
\hline 21 & $\begin{array}{l}\text { CIF Plant Purex } \\
\text { ashcrete }\end{array}$ & $<7.4 \times 10^{-10}$ & Pass & $<7.4 \times 10^{-9}$ & $\begin{array}{l}\text { Projected } \\
\text { Pass }\end{array}$ \\
\hline
\end{tabular}

The 10x correlation was used to estimate that Low Solids Portland cement Ashcrete centrifuge method results would meet permeability requirements. Low Solids Portland cement blowcrete made with 1 and $40 \mathrm{wt} \%$ scrubber solution centrifuge permeability results does not meet SRS requirements.

Low Solids Super Cement ${ }^{\mathrm{TM}}$ permeability results are given in Table XIV.

Table XIV. Low Solids Super Cement ${ }^{\mathrm{TM}}$ Permeabilities

\begin{tabular}{llllll}
$\begin{array}{l}\text { Sample Sample } \\
\text { Number Description }\end{array}$ & $\begin{array}{c}\text { Falling Head } \\
\text { Permeability } \\
(\mathrm{cm} / \mathrm{s})\end{array}$ & $\begin{array}{c}\text { E-Area } \\
\text { WAC }\end{array}$ & $\begin{array}{c}\text { Est. Centrif. } \\
\text { Permeability } \\
(\mathrm{cm} / \mathrm{s})\end{array}$ & $\begin{array}{l}\text { E-Area } \\
\text { WAC }\end{array}$ \\
\hline $27 \quad \begin{array}{l}\text { ashcrete with } \\
\text { setting agent }\end{array}$ & $6.7 \times 10^{-10}$ & Pass & $6.7 \times 10^{-9}$ & $\begin{array}{l}\text { Projected } \\
\text { Pass }\end{array}$ \\
$28 \quad \begin{array}{l}\text { ashcrete no } \\
\text { setting agent }\end{array}$ & $1.6 \times 10^{-9}$ & Pass & $1.6 \times 10^{-8}$ & $\begin{array}{l}\text { Projected } \\
\text { Fail }\end{array}$
\end{tabular}


Table XIV. Low Solids Super Cement ${ }^{\mathrm{TM}}$ Permeabilities Continued

\begin{tabular}{|c|c|c|c|c|c|}
\hline $\begin{array}{l}\text { Sample } \\
\text { Number }\end{array}$ & $\begin{array}{l}\text { Sample } \\
\text { Description }\end{array}$ & $\begin{array}{l}\text { Falling Head } \\
\text { Permeability } \\
(\mathrm{cm} / \mathrm{s})\end{array}$ & $\begin{array}{l}\text { E-Area } \\
\text { WAC }\end{array}$ & $\begin{array}{l}\text { Est. Centrif. } \\
\text { Permeability } \\
(\mathrm{cm} / \mathrm{s}) \\
\end{array}$ & $\begin{array}{l}\text { E-Area } \\
\text { WAC }\end{array}$ \\
\hline 25 & $\begin{array}{l}\text { blowcrete } \\
\text { with } 40 \text { wt } \% \\
\text { solids scrub. solution }\end{array}$ & $\begin{array}{l}7.5 \times 10^{-7} \\
\text { on }\end{array}$ & Fail & $7.5 \times 10^{-6}$ & $\begin{array}{l}\text { Projected } \\
\text { Fail }\end{array}$ \\
\hline 23 & $\begin{array}{l}\text { blowcrete } \\
\text { with } 10 \mathrm{wt} \% \\
\text { solids scrub. solutior }\end{array}$ & $1.5 \times 10^{-9}$ & Pass & $1.5 \times 10^{-8}$ & $\begin{array}{l}\text { Projected } \\
\text { Fail }\end{array}$ \\
\hline
\end{tabular}

Centrifuge permeabilities for Super Cement ${ }^{\mathrm{TM}}$ waste forms made with all concentrations of blowdown fail to meet acceptance criteria. Ashcrete Super Cement ${ }^{\mathrm{TM}}$ waste forms made without the setting agent fail permeability requirements but ashcrete with setting agent passes.

\section{Compressive Strength}

Compressive strengths of all samples tested except for High Solids Super Cement ${ }^{\mathrm{TM}}$ ashcrete without calcium hydroxide additive were greater than $700 \mathrm{psi}$ using the penetrometer method.

\section{Leaching Results}

A sample of High Solids ash submitted for Toxicity Characteristic Leaching Procedure (TCLP) testing without solidification passed all SRS leachability limits. The following are the analytical results for SRS High Solids ash TCLP before solidification:

$\begin{array}{llllllll}\mathrm{Hg} & \mathrm{Ag} & \mathrm{As} & \mathrm{Ba} & \mathrm{Cd} & \mathrm{Cr} & \mathrm{Pb} & \mathrm{Se} \\ <\mathrm{DL} & <\mathrm{DL} & 0.099 & 0.243 & 0.011 & 0.046 & 0.023 & 0.032\end{array}$

Initially blowdown solution contained:

$\begin{array}{ll}\text { Mercury } & <.01 \mathrm{ppm} \\ \text { Silver } & <0.025 \mathrm{ppm} \\ \text { Arsenic } & 2.56 \mathrm{ppm} \\ \text { Barium } & 0.12 \mathrm{ppm} \\ \text { Cadmium } & 0.211 \mathrm{ppm} \\ \text { Chromium } & 2.11 \mathrm{ppm} \\ \text { Lead } & 0.325 \mathrm{ppm} \\ \text { Selenium } & 0.65 \mathrm{ppm}\end{array}$


Only selenium was outside SRS TCLP limits which are based on 40CFR 268.48 Universal Treatment Standards (UTS). For the eight RCRA metals the limits are: Mercury $\quad 0.025 \mathrm{ppm}$

$\begin{array}{ll}\text { Silver } & 0.3 \mathrm{ppm} \\ \text { Arsenic } & 5 \mathrm{ppm} \\ \text { Barium } & 7 \mathrm{ppm} \\ \text { Cadmium } & 0.69 \mathrm{ppm} \\ \text { Chromium } & 0.86 \mathrm{ppm} \\ \text { Lead } & 0.37 \mathrm{ppm} \\ \text { Selenium } & 0.16 \mathrm{ppm}\end{array}$

TCLP results are given in Table XV for selected representative High Solids Portland cement waste forms made with SRS incinerator waste. The concentrations of the hazardous metals in the leachate meet SRS TCLP limits.

Table XV. TCLP Results for High Solids Portland Cement Waste Forms (mg/liter)

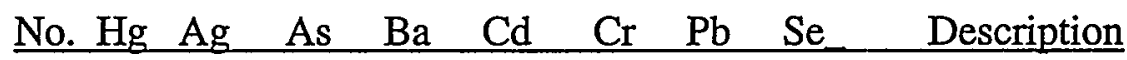

$1<\mathrm{DL} \quad 0.02<\mathrm{DL} \quad 0.98<\mathrm{DL} \quad 0.05<\mathrm{DL} \quad 0.03$

$2<\mathrm{DL} \quad 0.01<\mathrm{DL} \quad 0.47<\mathrm{DL} \quad 0.08<\mathrm{DL} 0.06$

$5<\mathrm{DL} \quad 0.01<\mathrm{DL} \quad 0.65<\mathrm{DL} \quad 0.07<\mathrm{DL} \quad 0.05$

$4<\mathrm{DL} \quad 0.01<\mathrm{DL} \quad 0.87<\mathrm{DL} \quad 0.04<\mathrm{DL} 0.03$

$3<\mathrm{DL} \quad 0.02<\mathrm{DL} \quad 0.81<\mathrm{DL} \quad 0.06<\mathrm{DL} \quad 0.04$
P. Cem.10wt \% T. Solids

P. Cem.30wt \% T. Solids

P. Cem.30wt \% T. Solids \& ash

P. Cem.10wt \% T. Solids \& ash

P. Cem. and ash only

$\angle D L$ means less than the detectable limit. These limits are $\mathrm{CrDL}=.0056, \mathrm{AsDL}=.045$, $\mathrm{SeDL}=.0045, \mathrm{BaDL}=.0051, \mathrm{CdDL}=.0044, \mathrm{AgDL}=.0073, \mathrm{PbDL}=.0159, \mathrm{HgDL}=.00035$

All Portland Cement ${ }^{\mathrm{TM}}$ samples pass leaching requirements for RCRA metals. Waste forms in samples 1,2,5,4 made with blowdown show a decrease in all chemical species except for barium. The selenium level in the blowdown which initially exceeded limits is within compliance after solidification. The waste form in sample 3 made with SRS ash shows a decrease in chemical species leaching except for barium and silver. Chromium and selenium levels in ash sample 3 remained about the same before and after solidification.

All High Solids Super Cement ${ }^{\mathrm{TM}}$ Samples meet leaching requirements and were covered in a previous MWFA report ${ }^{1}$. Super Cement ${ }^{\mathrm{TM}}$ waste form samples made with scrubber solution showed a decrease in chemical species except for barium which showed an increase possibly from the Super Cement ${ }^{\mathrm{TM}}$ changing barium bound in the blowdown in a non leachable form to a leachable form.

High Solids Super Cement ${ }^{\mathrm{TM}}$ sample made with only ash showed a decrease in chemical species except for barium which remained relatively constant. Samples made with a 
combination of ash and blowdown showed a leaching decrease in chemical species except for barium which showed an increase.

A sample of Low Solids ash submitted for TCLP without solidification passed all SRS leachability limits. The following are the analytical results for SRS Low Solids ash TCLP:

$\begin{array}{llllllll}\mathrm{Hg} & \mathrm{Ag} & \mathrm{As} & \mathrm{Ba} & \mathrm{Cd} & \mathrm{Cr} & \mathrm{Pb} & \mathrm{Se} \\ .0035 & .0015 & 0.039 & 0.251 & 0.018 & 0.042 & 0.012 & 0.0054\end{array}$

Initially blowdown solution contained:

$\begin{array}{ll}\text { Mercury } & <\mathrm{DL} \\ \text { Silver } & <0.003 \mathrm{ppm} \\ \text { Arsenic } & 0.024 \mathrm{ppm} \\ \text { Barium } & 0.085 \mathrm{ppm} \\ \text { Cadmium } & 0.032 \mathrm{ppm} \\ \text { Chromium } & 0.009 \mathrm{ppm} \\ \text { Lead } & 0.037 \mathrm{ppm} \\ \text { Selenium } & <0.015 \mathrm{ppm}\end{array}$

No heavy metal concentration was outside SRS TCLP limits which are based on 40CFR 268.48 Universal Treatment Standards.

Toxicity Characteristic Leaching Procedure (TCLP) results are given in Table XVI for selected representative Low Solids waste forms made with SRS incinerator waste.

The concentrations of the hazardous metals in the leachate meet SRS TCLP limits.

Table XVI. TCLP Results for Low Solids Waste Forms (mg/liter)

No. $\mathrm{Hg} \quad \mathrm{Ag}$ As $\mathrm{Ba} \quad \mathrm{Cd} \quad \mathrm{Cr} \quad \mathrm{Pb} \quad \mathrm{Se}$ Description

$26<\mathrm{DL} 0.02<\mathrm{DL} 0.66<\mathrm{DL}<\mathrm{DL}<\mathrm{DL} 0.03$

S. Cem. 1wt\%T. Solids

$23<\mathrm{DL} 0.02<\mathrm{DL} 0.88<\mathrm{DL}<\mathrm{DL}<\mathrm{DL} 0.04$

S. Cem. 10wt\%T. Solids

$25<\mathrm{DL} 0.01<\mathrm{DL} \quad 0.16<\mathrm{DL}<\mathrm{DL}<\mathrm{DL} 0.05$

S. Cem. 40wt\%T. Solids

$27<\mathrm{DL} \quad 0.02 \quad 0.08 \quad 0.58<\mathrm{DL}<\mathrm{DL}<\mathrm{DL}<\mathrm{DL}$

$\mathrm{S}$. Cem. Ash with set agent

$28<\mathrm{DL} \quad 0.02 \quad 0.09 \quad 0.75<\mathrm{DL}<\mathrm{DL}<\mathrm{DL}<\mathrm{DL}$

S. Cem. Ash no set agent

$17<\mathrm{DL} 0.02<\mathrm{DL} \quad 1.01<\mathrm{DL} 0.03<\mathrm{DL}<\mathrm{DL}$

P. Cem. 10 wt \% T. Solids

$20<\mathrm{DL} 0.02<\mathrm{DL} \quad 0.91<\mathrm{DL} \quad 0.03<\mathrm{DL}<\mathrm{DL}$

P. Cem. ash

$18<\mathrm{DL} 0.01<\mathrm{DL} \quad 0.27<\mathrm{DL} \quad 0.16<\mathrm{DL} \quad 0.05$

P. Cem. 40 wt $\%$ T. Solids

$19<\mathrm{DL} 0.02<\mathrm{DL} \quad 1.23<\mathrm{DL} \quad 0.04<\mathrm{DL} \quad 0.04$

P. Cem. ash .

$15<\mathrm{DL} 0.02<\mathrm{DL} \quad 0.79<\mathrm{DL} 0.06<\mathrm{DL} 0.05$

P. Cem. $1 \mathrm{wt} \%$ T. Solids 
All Low Solids Super Cement ${ }^{\mathrm{TM}}$ samples meet SRS leaching requirements. Low Solids Super Cement ${ }^{\mathrm{TM}}$ samples 26, 23, 25 made with different concentrations of blowdown showed a decrease in leaching for RCRA metals except for silver and barium. Low Solids Ash Super Cement ${ }^{\mathrm{TM}}$ samples showed a decrease in RCRA metals except for arsenic and barium. All Low Solids Portland cement samples made with blowdown and/or ash meet SRS leaching requirements. The leaching of metals decreased from the original blowdown and ash except for silver, barium, and selenium.

\section{Waste Loading Results}

The typical Portland cement plant waste loadings are $23.9 \mathrm{wt} \%$ for ash (on a dry ash basis) and 46.1 wt \% for scrubber solution. Plant formulations are based on previous work performed by Don Fisher at SRS. ${ }^{3,4}$

High Solids Super Cement ${ }^{\mathrm{TM}}$ waste loadings are given in Table XVII.

Table XVII. High Solids Super Cement ${ }^{\mathrm{TM}}$ Waste Loadings

\begin{tabular}{llll} 
& \multicolumn{3}{c}{ Wt\% } \\
Sample & Wt\% & SRS & Blowdown (BD) \\
Number & Bd & Ash & Total Solids Wt \% \\
\hline 7 & 0 & 28.3 & 0 \\
8 & 0 & 27.4 & 0 \\
9 & 0 & 26.3 & 0 \\
10 & 0 & 29.5 & 0 \\
13 & 41.4 & 0 & 30 \\
14 & 39.2 & 0 & 10
\end{tabular}

Low Solids Super Cement ${ }^{\mathrm{TM}}$ waste loadings are given in Table XVIII.

Table XVIII. Low Solids Super Cement ${ }^{\mathrm{TM}}$ Waste Loadings

\begin{tabular}{lllc} 
& \multicolumn{3}{c}{ Wt\% } \\
Sample & Wt\% & SRS & Blowdown (BD) \\
Number & Bd & Ash & Total Solids Wt \% \\
\hline 22 & 40.3 & 0 & 20 \\
23 & 39.1 & 0 & 10 \\
24 & 41.4 & 0 & 30 \\
25 & 41.6 & 0 & 40 \\
26 & 36.4 & 0 & 1 \\
27 & 0 & 35.0 & 0 \\
28 & 0 & 40.3 & 0
\end{tabular}


WSRC-TR-99-00359

September 30, 1999

Page 25 of 27

Notes for Tables XVII and XVIII:

1) $\mathrm{Wt} \% \mathrm{Bd}$ is the amount in grams of the blowdown or scrubber solution divided by the total weight of the sample that was incorporated in the waste form.

2) BD Total Solids Wt \% is the concentration of the blowdown (scrubber solution) that was incorporated in the waste form.

3) Wt \% SRS ash is on a dry basis

Waste loadings for High Solids Super Cement ${ }^{\mathrm{TM}}$ samples made with ash were higher than Portland cement. Waste loadings for High Solids Super Cement ${ }^{\mathrm{TM}}$ samples made with only scrubber solution were slightly less than those for the plant. Samples were made with 10 and 30 wt \% scrubber solution which is not performed at the SRS incinerator currently. These concentrations were run because an evaporator is planned as part of plant modifications. Since the blowdown used was concentrated the actual waste loadings will be greater than that achieved by the plant.

Waste loadings for Low Solids Super Cement ${ }^{\mathrm{TM}}$ were higher than Portland cement for samples made with ash and slightly lower than samples made with blowdown.

\section{CONCLUSIONS}

Portland cement and Super Cement ${ }^{\mathrm{TM}}$ waste forms meet set time, bleed water, mixability, compression, and leaching requirements for High and Low Solids. High Solids Portland cement centrifuge permeability is acceptable for $10 \mathrm{wt} \%$ total solids scrubber solution but fails at higher concentrations. High Solids Portland cement permeabilities of ash waste forms meet SRS criteria.

High Solids Super Cement ${ }^{\mathrm{TM}}$ ash or scrubber solution (at $30 \mathrm{wt} \%$ solids) waste forms fail permeability criteria. $10 \mathrm{wt} \%$ scrubber solution High Solids Super Cement ${ }^{\mathrm{TM}}$ waste form permeability could not be determined because of cracking of the sample. Low Solids Portland cement and Super Cement ${ }^{\mathrm{TM}}$ ash waste forms pass permeability requirements but waste forms made with all concentrations of scrubber solution fail for both technologies.

The viscosity of High Solids Super Cement ${ }^{\mathrm{TM}}$ samples is comparable to samples made with Portland cement. Bleed water was observed initially for Super Cement ${ }^{\mathrm{TM}}$ made with blowdown but was absorbed after 24 hours.

From a processibility stand point Super Cement ${ }^{\mathrm{TM}}$ will present more problems than Portland cement because of additional reagents (hardening, TMT15, sodium sulfide) that need to be added. Portland cement uses only the cement mix and water with no plant modifications. 
Setting problems with the High Solids Super Cement ${ }^{\mathrm{TM}}$ waste forms made with only ash were overcome by adding calcium hydroxide or Portland cement to the ash before mixing with Super Cement ${ }^{\mathrm{TM}}$ and water.

High Solids waste forms made with Super Cement ${ }^{\mathrm{TM}}$ meet all SRS acceptance criteria except permeability and have a waste loading similar to the current Portland cement technology employed. Samples made with scrubber solution were slightly less than the waste loading of Portland cement. The actual waste loadings of blowdown waste forms for Super Cement ${ }^{\mathrm{TM}}$ is actually greater than the plant waste loadings because samples in this study were concentrated up to 20 and $30 \mathrm{wt} \%$ total solids whereas the plant blowdown concentration is only $10 \mathrm{wt} \%$ total solids.

Solid waste forms made with scrubber solution are thought to be more permeable because of the effect of excess salt. The phenomenon occurs because water flowing through the solid waste form dissolves away the salt and thereby opens the porosity. In addition, the salts affect the water/cement ratio required to obtain processable mixtures. The higher the water to cement ratio the higher the porosity and permeability. The combination of salt and uncombined water can cause additional pore space if it is washed out which results in increased permeability.

There are no clear advantages to using Super Cement ${ }^{\mathrm{TM}}$ instead of Portland cement for Low Solids waste at this time other than the Super Cement ${ }^{\mathrm{TM}}$ ash waste forms do not have bleed water problems like Portland cement ash waste forms. Portland cement ash waste form bleed water is taken care of in the plant by adding Portland cement to react with the bleed water. Super Cement ${ }^{\mathrm{TM}}$ and Portland cement Low Solid waste forms made with scrubber solution both fail permeability criteria which eliminates the possibility of solidifying this secondary waste stream.

Portland cement High Solids ash waste forms and $10 \mathrm{wt} \%$ scrubber waste forms pass permeability criteria but $30 \mathrm{wt} \%$ scrubber waste forms do not. Permeability requirements are not met for any of the High Solids Super Cement ${ }^{\mathrm{TM}}$ ash or $30 \mathrm{wt} \%$ scrubber waste forms and could not be determined for $10 \mathrm{wt} \%$ scrubber waste forms. At this time, permeability is not a requirement for disposing of High Solids solid waste forms. Since disposal is not by trench burial at SRS this may not be an issue. If permeability is not an issue for High Solids waste forms then either technology will be acceptable for solidification.

\section{RECOMMENDATIONS}

Super Cement ${ }^{\mathrm{TM}}$ does not have clear advantages over Portland cement and requires additional expense to incorporate. Neither technology creates a waste form with acceptable permeability when concentrated scrubber solutions are stabilized. This is a potential issue if the plant desires to stabilize concentrated solutions from a new evaporator to be added in the near future. 
Most of the waste forms for both the High and Low Solids meet the acceptance criteria except for permeability. The high salt in the concentrated scrubber solution apparently causes waste forms with unacceptable permeabilities. Most of the permeability values of blowdown marginally fail to meet acceptance criteria.

Permeability is one of the parameters in a performance assessment model, which predicts leaching to the environment. If the plant needs to solidify concentrated high or low solids scrubber solution and dispose of the solid waste forms in trenches (trench disposal requires meeting permeability criteria at this time) the performance assessment model should be evaluated again to see if the permeability limit can be lowered to around $1 \times 10^{-6} \mathrm{~cm} / \mathrm{sec}$ and still achieve acceptable leaching levels.

Another possibility to try and solve the permeability problem is to modify the Portland and Super Cement ${ }^{\mathrm{TM}}$ formulation to deal with the high salt problem in the blowdown.

\section{QUALITY ASSURANCE}

Quality Assurance testing was conducted in accordance with SRS procedures. Results are recorded in Laboratory Notebook WSRC-NB-96-633. The Technical Task Plan and Quality Assurance Plan are documented in WSRC-RP-99-013615.

Centrifuge analyses performed by UFA Ventures have been accepted to ASTM D18.21 Subcommittee on Ground Water.

\section{ACKNOWLEDGEMENTS}

This work was done as part of the DOE Office of Science and Technology, Mixed Waste Focus Area program (TTP SR1-8-MW-44).

\section{REFERENCES}

1. B. W. Walker, "High Solids Consolidated Incinerator Facility (CIF) Wastes Stabilization with Ceramicrete and Super Cement," Rev. 0. WSRC-TR-99-00182, June 1, 1999.

2. 40 CFR 268.48, Code of Federal Regulations 40, "Protection of Environment" Section 268.48 .

3. D.L. Fisher,1995, "CIF Blowdown Stabilization: Formula Development Report ," WSRC-TR95-00114, March 9, 1995.

4. D.L. Fisher,1996, “CIF Ashcrete Mixture Limits,” WSRC-TR-96-0169, June 14, 1996.

5. B. W. Walker, "Technical Task Plan for Mixed Waste Focus Area (MWFA) Evaluation of Salt Waste Treatment Technologies," WSRC-RP-98-01361, March 6, 1998. 
Appendix 1.

Characterization of Incinerator Waste 
High Solids Off Gas Scrubber Solution (Blowdown) Characterization

Characterization of the incinerator blowdown is given below. The quench system is operated to produce blowdown containing close to $10 \%$ total solids. The suspended solids of the blowdown used in this study were $1.5 \%$ and contained mostly $\mathrm{SiO}_{2}$ and $\mathrm{Zn}(\mathrm{OH})_{2}$. Dissolved solids results from analyses on plant samples were $8.2 \%$ and are usually $\mathrm{NaCl}$ and $\mathrm{Na}_{2} \mathrm{SO}_{4}$. The $\mathrm{pH}$ of the blowdown was 8.77 and the water content $90.3 \%$.

\begin{tabular}{lc} 
Component & (mg/liter) \\
\hline Aluminum & 541.5 \\
Calcium & 600.3 \\
Iron & 545.3 \\
Magnesium & 178.0 \\
Sodium & 32126.8 \\
Fluoride & 639.0 \\
Formate & $<10.0$ \\
Chloride & $19,618.0$ \\
Nitrite & 230.0 \\
Nitrate & 274.0 \\
Phosphate & 260.0 \\
Sulfate & 40247.0 \\
Oxalate & $<10.0$
\end{tabular}

High Solids Ash Characterization

High Solids ash characterization of the incinerator ash is given in Table IV.

Table IV. High Solids Ash Characterization

Based on X-ray diffraction the ash contained :

Cristobalite; $\mathrm{SiO}_{2}$

Silicon oxide; $\mathrm{SiO}_{2}$

Anorthoclase; $\left(\mathrm{NaK}_{2}\right)\left(\mathrm{AlSi}_{3} \mathrm{O}_{8}\right)$

Magnetite; $\mathrm{Fe}_{3} \mathrm{O}_{4}$

Hematite; $\mathrm{Fe}_{2} \mathrm{O}_{3}$.

The ash was wet quenched and contained $45+/-15 \%$ quench water. Ash used in this study was drained of excess water which resulted in a water content of about $25 \%$. The $\mathrm{pH}$ of the water in contact with the ash was 10.55 . 
WSRC-TR-99-00359

Revision 0

September 30, 1999

Page A1 -3

Low Solids Off Gas Scrubber Solution (Blowdown) Characterization

Soluble solids were $1 \%$ (wt./vol.). Insoluble solids were $0.2 \%$ (wt./vol.). Most of the solids ( $>99 \%$ ) were soluble in a hot $30 \mathrm{wt} \% \mathrm{NaOH}$ solution. The bulk of the insolubles are likely alumina, silica, and probably titanium dioxide. There was no detectable soluble mercury. The density of the blow down was $1.01 \mathrm{~g} / \mathrm{ml}$ and the $\mathrm{pH}$ was 7.5 .

Gross alpha was $539 \mathrm{dpm} / \mathrm{ml}$

Gross beta was $240 \mathrm{dpm} / \mathrm{ml}$

Gross gamma was $154 \mathrm{dpm} / \mathrm{ml}$

Tritium was $1302 \mathrm{dpm} / \mathrm{ml}$

Gamma Contributors

Activity Component

$3.85 \mathrm{pCi} / \mathrm{ml} \quad \mathrm{K}-40$

$1.31 \mathrm{pCi} / \mathrm{ml} \quad \mathrm{Co}-60$

$226 \mathrm{pCi} / \mathrm{ml} \quad \mathrm{Cs}-137$

$2.52 \mathrm{pCi} / \mathrm{ml} \quad \mathrm{Eu}-154$

$7.69 \mathrm{pCi} / \mathrm{ml} \quad \mathrm{Am}-241$

Component (mg/liter) Component (mg/liter)

$\begin{array}{llll}\text { Silver } & <0.003 & \text { Manganese } & 0.712 \\ \text { Aluminum } & <0.060 & \text { Molybdenum } & 0.776 \\ \text { Arsenic } & 0.024 & \text { Sodium } & 2459 \\ \text { Boron } & 7.75 & \text { Nickel } & 0.075 \\ \text { Barium } & 0.085 & \text { Lead } & 0.037 \\ \text { Beryllium } & <0.0004 & \text { Selenium } & <0.015 \\ \text { Calcium } & 39.16 & \text { Antimony } & 10.64 \\ \text { Cadmium } & 0.032 & \text { Silicon } & 69.5 \\ \text { Chromium } & 0.009 & \text { Strontium } & 0.065 \\ \text { Cesium } & <10 & \text { Thorium } & <0.50 \\ \text { Copper } & 1.66 & \text { Titanium } & <0.001 \\ \text { Iron } & 0.252 & \text { Thallium } & <0.015 \\ \text { Potassium } & 92.53 & \text { Uranium } & <0.15 \\ \text { Magnesium } & 12.26 & \text { Vanadium } & 0.091 \\ \text { Zinc } & 2.43 & \text { Zirconium } & <0.035 \\ \text { Chloride } & 988 & \text { Sulfate } & 2050\end{array}$

Carbonate $\quad 105$ 


\section{Low Solids Ash Characterization}

The ash was wet quenched and contained $45+/-15 \mathrm{wt}$. \% quench water. Ash used in this study was drained of excess water which resulted in a water content of about 25 wt. \%. The $\mathrm{pH}$ of the water in contact with the ash was 10.6.

\begin{tabular}{llll} 
Component & $(\mathrm{mg} /$ liter $)$ & Component & $(\mathrm{mg} /$ liter $)$ \\
\hline Mercury & 0.0042 & Selenium & 0.255 \\
Silver & 0.226 & Antimony & 29.7 \\
Arsenic & 6.96 & Thallium & 0.416 \\
Barium & 238 & Copper & 646 \\
Beryllium & 0.266 & Iron & 6400 \\
Cadmium & 2.57 & Manganese & 153 \\
Chromium & 16.9 & Sodium & 5450 \\
Nickel & 87.4 & Titanium & 3.9 \\
Lead & 44.8 & Zinc & 846 \\
Cobalt & 3.43 & &
\end{tabular}


WSRC-TR-99-00359

Revision 0

September 30, 1999

Page A2 -1

Appendix 2.

Permeability Calculations 
Table A2.1 Measurements and Results of Falling Head Permeability Tests.

\begin{tabular}{|c|c|c|c|c|c|c|c|c|c|c|c|c|c|}
\hline & L & D & A & $\begin{array}{l}\text { Man. } \\
\text { Ht. } 1\end{array}$ & $\begin{array}{l}\text { Man. } \\
\text { Ht } 2\end{array}$ & $\begin{array}{c}\text { Man. } \\
\text { Ht ave. }\end{array}$ & P1 & P2 & $\begin{array}{l}\text { Hyd. } \\
\text { Head }\end{array}$ & $\begin{array}{l}\text { Vol. } \\
\text { Coll. }\end{array}$ & $\begin{array}{l}\text { Coll. } \\
\text { Time }\end{array}$ & $\begin{array}{c}\text { Flow } \\
\text { Rate } Q\end{array}$ & $\begin{array}{c}\text { Hyd. } \\
\text { Cond. K }\end{array}$ \\
\hline & $(\mathrm{cm})$ & $(\mathrm{cm})$ & (cm2) & $\mathbf{c m}$ & $\mathrm{cm}$ & $\mathrm{cm}$ & psig & psig & $\mathrm{cm}$ & $\mathrm{cm3}$ & $\mathrm{hr}$ & $(\mathrm{cm} 3 / \mathrm{s})$ & $(\mathrm{cm} / \mathrm{s})$ \\
\hline \multicolumn{14}{|l|}{ Sample 11 } \\
\hline 10wtNaCl & $\begin{array}{l}\text { PC } \\
\text { LS }\end{array}$ & & & & & & & & & & & & \\
\hline Actual & 0.80 & 3.10 & 7.54 & 2.00 & 3.00 & 2.50 & 10.00 & 0.00 & 705.60 & 0.00 & 12.00 & $0.00 \mathrm{E}+00$ & $0.00 E+00$ \\
\hline Detect & 0.80 & 3.10 & 7.54 & 2.00 & 3.00 & 2.50 & 10.00 & 0.00 & 705.60 & 0.05 & 12.00 & $1.16 \mathrm{E}-06$ & $1.74 \mathrm{E}-10$ \\
\hline
\end{tabular}

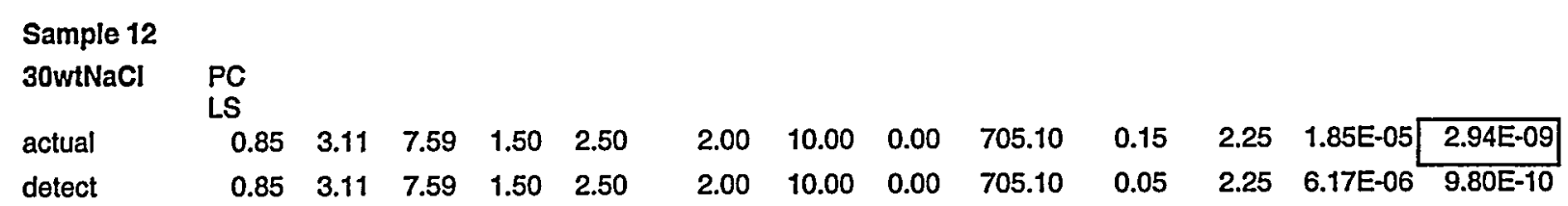

\section{Sample 15}

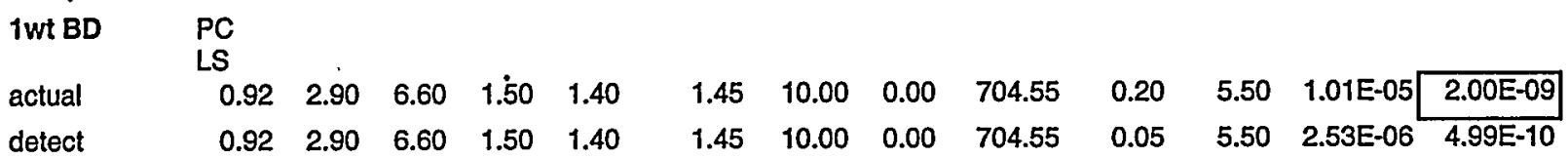

Sample 18

\begin{tabular}{|c|c|c|c|c|c|c|c|c|c|c|c|c|c|}
\hline 40wt BD & $\begin{array}{l}\text { PC } \\
\text { LS }\end{array}$ & & & & & & & & & & & & \\
\hline actual & 0.99 & 3.10 & 7.54 & 2.00 & 1.90 & 1.95 & 10.00 & 0.00 & 705.05 & 0.90 & 5.50 & 4.55E-05 & $8.46 E-09$ \\
\hline detect & 0.99 & 3.10 & 7.54 & 2.00 & 1.90 & 1.95 & 10.00 & 0.00 & 705.05 & 0.05 & 5.50 & 2.53E-06 & $4.70 \mathrm{E}-10$ \\
\hline
\end{tabular}

Sample 19

Ash SRTC

PC

actual

$\begin{array}{lllll}0.81 & 3.10 & 7.54 & 1.00 & 0.90\end{array}$

$\begin{array}{llllllll}0.95 & 10.00 & 0.00 & 704.05 & 0.00 & 5.08 & 0.00 E+00 & 0.00 E+00\end{array}$

detect

$\begin{array}{lllll}0.81 & 3.10 & 7.54 & 1.00 & 0.90\end{array}$

$\begin{array}{llll}0.95 & 10.00 & 0.00 & 704.05\end{array}$

$0.05 \quad 5.08 \quad 2.73 E-06 \quad 4.17 E-10$

\section{Sample 21}

$\begin{array}{ll}\text { Ash CIF } & \text { PC } \\ \text { actual } & \text { LS }\end{array}$

PC

detect

$\begin{array}{lllll}1.50 & 3.20 & 8.04 & 1.10 & 1.00\end{array}$

$\begin{array}{llll}1.60 & 10.00 & 0.00 & 704.70\end{array}$

0.00

$5.00 \quad 0.00 E+00 \quad 0.00 E+00$

$\begin{array}{llllll}1.50 & 3.20 & 8.04 & 1.10 & 1.00\end{array}$

$\begin{array}{llll}1.60 & 10.00 & 0.00 & 704.70\end{array}$

$0.05 \quad 5.00 \quad 2.78 E-06 \quad 7.36 \mathrm{E}-10$

* $0.05 \mathrm{~cm}^{3}$ is the minimum detectable volume which can be measured in the graduated buret. The permeability value reported as detectable is based on achieving steady state flow of $0.05 \mathrm{~cm}^{3}$ (ml) over the run time interval T2 - T1 reported for each sample. For samples having no actual flow $(\mathrm{Q})$ the permeabilities $(\mathrm{K})$ were reported as less than values using the minimum detectable flow as the upper-bound estimate. 
WSRC-TR-99-00359

Revision 0

September 30, 1999

Page A2 -3

\begin{tabular}{|c|c|c|c|c|c|c|c|c|c|c|c|c|c|}
\hline & $\mathbf{L}$ & D & A & $\begin{array}{l}\text { Man. } \\
\text { Ht. } 1\end{array}$ & $\begin{array}{l}\text { Man. } \\
\text { Ht } 2\end{array}$ & $\begin{array}{l}\text { Man. } \\
\text { Ht ave. }\end{array}$ & P1 & P2 & $\begin{array}{l}\text { Hyd. } \\
\text { Head }\end{array}$ & $\begin{array}{l}\text { Vol. } \\
\text { Coll. }\end{array}$ & $\begin{array}{l}\text { Coll. } \\
\text { Time }\end{array}$ & $\begin{array}{c}\text { Flow } \\
\text { Rate Q }\end{array}$ & $\begin{array}{c}\text { Hyd. } \\
\text { Cond. K }\end{array}$ \\
\hline & (cm) & (cm) & (cm2) & $\mathrm{cm}$ & $\mathrm{cm}$ & $\mathrm{cm}$ & psig & psig & $\mathrm{cm}$ & cm3 & hr & $(\mathrm{cm} 3 / \mathrm{s})$ & $(\mathrm{cm} / \mathrm{s})$ \\
\hline \multicolumn{14}{|l|}{ Sample 1} \\
\hline 10wt BD & & & & & & & & & & & & & \\
\hline actual & 1.30 & 3.10 & 7.54 & 1.20 & 1.10 & 1.15 & 10.00 & 0.00 & 704.25 & 0.00 & 5.50 & $0.00 \mathrm{E}+00$ & $0.00 E+00$ \\
\hline detect & 1.30 & 3.10 & 7.54 & 1.20 & 1.10 & 1.15 & 10.00 & 0.00 & 704.25 & 0.05 & 5.50 & $2.53 E-06[$ & $6.18 \mathrm{E}-10$ \\
\hline \multicolumn{14}{|l|}{ Sample 3} \\
\hline ash & $\mathrm{PC}$ & & & & & & & & & & & & \\
\hline actual & 1.15 & 3.20 & 8.04 & 1.20 & 0.30 & 0.75 & 10.00 & 0.00 & .703 .85 & 0.00 & 4.57 & $0.00 \mathrm{E}+00$ & $0.00 E+00$ \\
\hline detect & 1.15 & 3.20 & 8.04 & 1.20 & 0.30 & 0.75 & 10.00 & 0.00 & 703.85 & 0.05 & 4.57 & $3.04 \mathrm{E}-06$ & $6.18 E-10$ \\
\hline \multicolumn{14}{|l|}{ Sample 2} \\
\hline $30 \% \mathrm{BD}$ & $\begin{array}{l}\mathrm{PC} \\
\mathrm{HS}\end{array}$ & & & & & & & & & & & & \\
\hline actual & 1.30 & 3.30 & 8.55 & 1.20 & 0.30 & 0.75 & 10.00 & 0.00 & 703.85 & 2.80 & 0.40 & $1.94 \mathrm{E}-03$ & $4.20 E-07$ \\
\hline detect & 1.30 & 3.30 & 8.55 & 1.20 & 0.30 & 0.75 & 10.00 & 0.00 & 703.85 & 0.05 & 0.40 & 3.47E-05 & $7.50 \mathrm{E}-09$ \\
\hline \multicolumn{14}{|l|}{ Sample 8} \\
\hline ash & $\begin{array}{l}\text { SC } \\
\text { HS }\end{array}$ & & & & & & & & & & & & \\
\hline actual & 1.30 & 3.10 & 7.54 & 3.30 & 2.80 & 3.05 & 10.00 & 0.00 & 706.15 & 0.40 & 5.62 & $1.98 \mathrm{E}-05$ & $4.82 E-09$ \\
\hline detect & 1.30 & 3.10 & 7.54 & 3.30 & 2.80 & 3.05 & 10.00 & 0.00 & 706.15 & 0.05 & 5.62 & 2.47E-06 & $6.03 E-10$ \\
\hline \multicolumn{14}{|c|}{ Sample 13} \\
\hline BD30\% & $\begin{array}{l}\text { SC } \\
\text { HS }\end{array}$ & & & & & & & & & & & & \\
\hline actual & 1.10 & 3.10 & 7.54 & 3.30 & 2.80 & 3.05 & 10.00 & 0.00 & 706.15 & 2.00 & 0.25 & $2.22 \mathrm{E}-03$ & $4.59 E-07$ \\
\hline detect & 1.10 & 3.10 & 7.54 & 3.30 & 2.80 & 3.05 & 10.00 & 0.00 & 706.15 & 0.05 & 0.25 & 5.56E-05 & $1.15 E-08$ \\
\hline \multicolumn{14}{|c|}{ Sample 14} \\
\hline BD10\% & $\begin{array}{l}\text { SC } \\
\text { HS }\end{array}$ & & & & & & & & & & & & \\
\hline actual & 1.80 & 3.00 & 7.07 & 0.90 & 0.50 & 0.70 & 10.00 & 0.00 & 703.80 & 2.00 & 0.25 & $2.22 \mathrm{E}-03[$ & $8.04 \mathrm{E}-07$ \\
\hline detect & 1.80 & 3.00 & 7.07 & 0.90 & 0.50 & 0.70 & 10.00 & 0.00 & 703.80 & 0.05 & 0.25 & $5.56 \mathrm{E}-05$ & 2.01E-08 \\
\hline
\end{tabular}

Note: Sample 14 appears to be cracked which may give an erroneous permeability value. 


\begin{tabular}{|c|c|c|c|c|c|c|c|c|c|c|c|c|c|}
\hline & $\mathbf{L}$ & D & A & $\begin{array}{l}\text { Man. } \\
\text { Ht. } 1\end{array}$ & $\begin{array}{l}\text { Man. } \\
\text { Ht } 2\end{array}$ & $\begin{array}{l}\text { Man. } \\
\text { Ht ave. }\end{array}$ & P1 & P2 & $\begin{array}{l}\text { Hyd. } \\
\text { Head }\end{array}$ & $\begin{array}{l}\text { Yol. } \\
\text { Coll. }\end{array}$ & $\begin{array}{l}\text { Coll. } \\
\text { Time }\end{array}$ & $\begin{array}{c}\text { Flow } \\
\text { Rate Q }\end{array}$ & $\begin{array}{c}\text { Hyd. } \\
\text { Cond. K }\end{array}$ \\
\hline & (cm) & (cm) & (cm2) & $\mathrm{cm}$ & $\mathrm{cm}$ & $\mathrm{cm}$ & psig & psig & $\mathbf{c m}$ & $\mathrm{cm3}$ & $\mathrm{hr}$ & $(\mathrm{cm} 3 / \mathrm{s})$ & $(\mathrm{cm} / \mathrm{s})$ \\
\hline \multicolumn{14}{|l|}{ Sample 25} \\
\hline BD40\% & $\begin{array}{l}\text { SC } \\
\text { LS }\end{array}$ & & & & & & & & & & & & \\
\hline actual & 1.80 & 3.10 & 7.54 & 1.40 & 1.00 & 1.20 & 10.00 & 0.00 & 704.30 & 2.00 & 0.25 & $2.22 \mathrm{E}-03$ & $7.53 E-07$ \\
\hline detect & 1.80 & 3.10 & 7.54 & 1.40 & 1.00 & 1.20 & 10.00 & 0.00 & 704.30 & 0.05 & 0.25 & 5.56E-05 & $1.88 \mathrm{E}-08$ \\
\hline \multicolumn{14}{|l|}{ Sample 23} \\
\hline $10 \% B D$ & $\begin{array}{l}\text { SC } \\
\text { LS }\end{array}$ & & & & & & & & & & & & \\
\hline actual & 1.60 & 3.10 & 7.54 & 0.30 & 0.20 & 0.25 & 10.00 & 0.00 & 703.35 & 0.10 & 5.60 & 4.96E-06 & $1.50 \mathrm{E}-09$ \\
\hline detect & 1.60 & 3.10 & 7.54 & 0.30 & 0.20 & 0.25 & 10.00 & 0.00 & 703.35 & 0.05 & 5.60 & 2.48E-06 & $7.48 E-10$ \\
\hline Sample 27 & & & & & & & & & & & & & \\
\hline ashwset & $\begin{array}{l}\text { SC } \\
\text { LS }\end{array}$ & & & & & & & & & & & & \\
\hline actual & 1.40 & 3.10 & 7.54 & 1.10 & 1.00 & 1.05 & 10.00 & 0.00 & 704.15 & 0.00 & 5.50 & $0.00 \mathrm{E}+00$ & $0.00 E+00$ \\
\hline detect & 1.40 & 3.10 & 7.54 & 1.10 & 1.00 & 1.05 & 10.00 & 0.00 & 704.15 & 0.05 & 5.50 & $2.53 E-06$ & $6.66 \mathrm{E}-10$ \\
\hline \multicolumn{14}{|l|}{ Sample 28} \\
\hline ashnoset & $\begin{array}{l}\text { SC } \\
\text { LS }\end{array}$ & & & & & & & & & & & & \\
\hline actual & 0.81 & 3.10 & 7.54 & 1.00 & 0.90 & 0.95 & 10.00 & 0.00 & 704.05 & 0.15 & 4.00 & $1.04 \mathrm{E}-05$ & 1.59E-09 \\
\hline detect & 0.81 & 3.10 & 7.54 & 1.00 & 0.90 & 0.95 & 10.00 & 0.00 & 704.05 & 0.05 & 4.00 & 3.47E-06 & $5.30 \mathrm{E}-10$ \\
\hline
\end{tabular}


SRTC-TR-99-00359

Revision 0

September 30, 1999

Page A3 -1

Appendix 3.

Plant Algorithm for Waste Loadings 


\section{Calculations}

Comparison of waste loadings was performed by first determining the algorithm used by the plant to make Portland cement waste forms. For waste forms made with ash the algorithm is

$y=.05582 x^{4}-.51808 x^{3}+1.8576 x^{2}-3.5521 x+4.162$

Where $\mathrm{x}=$ water to ash ratio and $\mathrm{y}=$ slurry to cement ratio

This is used for $x$ values greater than or equal to 1 and values less than or equal to 3.25. Optimally the plant tries to achieve an $x$ value of 1.25 .

For our case the ash contained 25 grams of water in 100 grams of ash. Since this is not a 1.25 ratio water must be added to the ash (in this case 100 grams). Doing this gives $\mathrm{x}=$ 1.25 and using the equation we find $y=1.748$.

The amount of cement needed for mixing is found by dividing the slurry weight by $y$ : 200 grams of slurry $/ 1.748=114.4$ grams of Portland cement needed.

The plant typical ash waste loading is therefore

100 grams of wet ash $/ 314.4$ grams total mix times $100=31.8 \%$ wet ash . 75 grams of dry ash $/ 314.4$ grams total mix times $100=23.9 \%$ dry ash

Waste Loadings for plant Portland cement made with scrubber solution uses the formulation of water/cement $=.415 / 1$.

The plant scrubber solution contains approximately $10 \%$ wt total solids. For 100 grams of scrubber solution there is 90 grams of water. The amount of cement needed would therefore be 216.9 grams for this sample. A typical plant waste loading for scrubber solution is 100 grams of scrubber solution / 216.9 grams of total mix x $100=46.1 \%$. 